\title{
Acceptability and sustainability of the WHO focused antenatal care package in Kenya
}

Harriet Birungi

Population Council

Washington Onyango-Ouma

Follow this and additional works at: https://knowledgecommons.popcouncil.org/departments_sbsr-rh

Part of the Demography, Population, and Ecology Commons, International Public Health Commons, Maternal and Child Health Commons, and the Women's Health Commons How does access to this work benefit you? Let us know!

\section{Recommended Citation}

Birungi, Harriet and Washington Onyango-Ouma. 2006. "Acceptability and sustainability of the WHO focused antenatal care package in Kenya," FRONTIERS Final Report. Washington, DC: Population Council. 


\title{
Acceptability and Sustainability of the WHO Focused Antenatal Care package in Kenya
}

\author{
Harriet Birungi \& W. Onyango-Ouma \\ Frontiers in Reproductive Health Program, Population Council \\ Institute of African Studies, University of Nairobi
}

June 2006

This study was funded by the U.S. AGENCY FOR INTERNATIONAL DEVELOPMENT (USAID) under the terms of Cooperative Agreement Number HRN-A-00-98-00012-00 and Population Council Subagreement No.AI04.31A. The opinions expressed herein are those of the authors and do not necessarily reflect the views of USAID. 
ABBREVIATIONS AND ACRONYMS ................................................................................................... III

ACKNOWLEDGEMENTS ........................................................................................................................ IV

EXECUTIVE SUMMARY .................................................................................................................................V

1.0 BACKGROUND ..................................................................................................................1

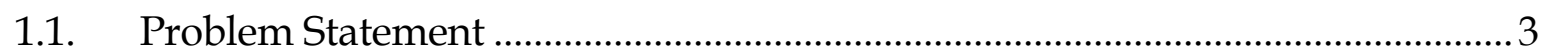

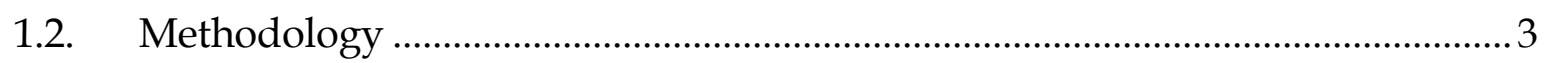

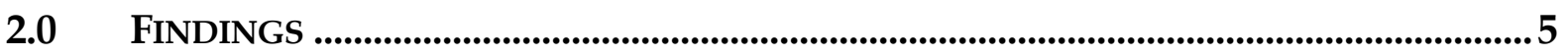

2.1 Recommended content of focused ANC in Kenya................................................ 6

2.1.1 Actual content of focused ANC offered service delivery level.................................... 6

2.2 Context for introduction of focused ANC ………………………………...........

2.3 Process of stimulating changes in ANC ......................................................... 9

2.3.1 Involvement of different actors........................................................................ 12

2.4 Clinic preparedness to offer focused ANC …………………………………......14

2.5 Awareness of focused ANC package and services .............................................14

2.5.1 Provider awareness of focused ANC ................................................................ 15

2.5.2 Client awareness of focused ANC ..................................................................... 17

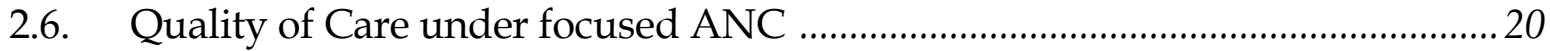

2.6.1 Comprehensive history taking............................................................................ 19

2.6.2 Detection of existing diseases ................................................................................2 22

2.6.3 Prevention of diseases and promotion of health ........................................................2 23

2.6.4 Preparation for birth and potential complications...................................................2. 25

2.6.5 Counseling on plans for postpartum care .............................................................2

2.6.6 Encouraging continuity and follow-up ..............................................................2 27

2.6.7 Provider and client satisfaction with focused ANC .............................................. 28

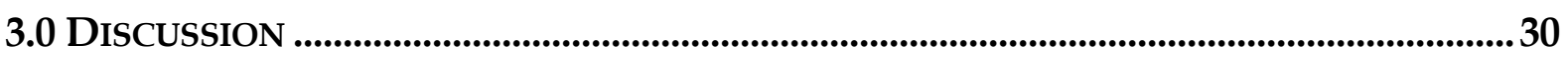

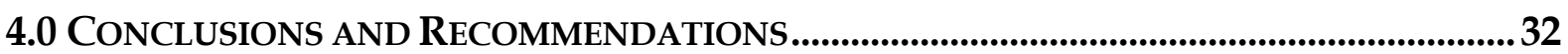

\section{REFERENCES}

ANNEX 1 


\section{Abbreviations and Acronyms}

$\begin{array}{ll}\text { AIDS } & \text { Acquired Immune Deficiency Syndrome } \\ \text { ANC } & \text { Antenatal Care } \\ \text { ARV } & \text { Antiretroviral } \\ \text { CHAK } & \text { Christian Health Association of Kenya } \\ \text { DFID } & \text { Department for Interventional Development } \\ \text { DHMT } & \text { District Health Management Teams } \\ \text { KDHS } & \text { Kenya Demographic and Health Survey } \\ \text { DRH } & \text { Division of Reproductive Health } \\ \text { DOMC } & \text { Division of Malaria Control } \\ \text { DOT } & \text { Direct Observed Treatment Short course } \\ \text { FGD } & \text { Focus Group Discussion } \\ \text { HIV } & \text { Human Immunodeficiency Virus } \\ \text { IBP } & \text { Individual Birth Plan } \\ \text { IPT } & \text { Intermittent Presumptive Treatment of malaria } \\ \text { JHPIEGO } & \text { Affiliate of Johns Hopkins University } \\ \text { KSPA } & \text { Kenya Service Provision Assessment } \\ \text { KES } & \text { Kenya Shillings } \\ \text { MOH } & \text { Ministry of Health } \\ \text { NGOs } & \text { Non-Governmental Organizations } \\ \text { PMTCT } & \text { Prevention of Mother to Child Transmission } \\ \text { RH } & \text { Reproductive Health } \\ \text { RTI } & \text { Reproductive Tract Infections } \\ \text { STI } & \text { Sexually Transmitted Infection } \\ \text { SP } & \text { Sulfadoxine-Pyrimethamine } \\ \text { SIDA } & \text { Swedish International Development Agency } \\ \text { TB } & \text { Tuberculosis } \\ \text { TT } & \text { Tetanus Toxoid } \\ \text { TOT } & \text { Training of Trainers } \\ \text { USAID } & \text { United States Agency for International Development } \\ \text { VCT } & \text { Voluntary Counselling and Testing } \\ \text { VDRL/RPR } & \text { Venereal Disease Research Laboratory/Rapid Plasma Reagin } \\ \text { WHO } & \text { World Health Organization } \\ & \end{array}$




\section{Acknowledgements}

We would like to acknowledge administrative support received from the Director of the Institute of African Studies, Prof Isaac Nyamongo. We also acknowledge Owuor Olungah of the Institute of African Studies, University of Nairobi for his contribution as study co-investigator during proposal development, study tools development, training of research assistants and initial fieldwork implementation.

We are very grateful to the technical support received from Ian Askew, John Townsend and Joanne Gleason of the Frontiers in Reproductive Health Program, Population Council. The technical advice received from Charlotte Warren, Wilson Liambila and Annie Mwangi of the Global Reproductive Health Program, Population Council is also greatly appreciated.

During fieldwork, several research assistants provided valuable assistance that made the situation and policy analysis possible. We would also like to thank Joyce Ombeva of the Population Council, Nairobi and George Odingo for their respective administrative and data management support throughout the study.

Our appreciation also goes to Dr. Marsden Solomon, Dr. Margaret Meme and Dr. Josphine Kibaru of the Division of Reproductive Health, Ministry of Health for reviewing the study proposal and providing in-depth information about focused antenatal care in Kenya. We would also like to thank all members of the Busia, Lugari and Siaya District Health Management Teams as well as service providers at various public health facilities for their cooperation and insightful contribution to the study.

Above all, we would like to thank all other individuals not listed here who agreed to participate in this study. 


\section{Executive Summary}

To promote the health and survival of mothers and babies, Kenya has adapted the WHO goal-oriented Antenatal Care (ANC) package, popularly known as focused ANC (FANC). The Ministry of Health (MOH) has designed new guidelines for ANC services, placing emphasis on refocusing antenatal care, birth planning and emergency preparedness, and the identification, prevention and management of life threatening complications during pregnancy and childbirth. ANC visits are now used as an entry point for a range of other services, thus promoting comprehensive integrated service delivery. A major challenge, however, is whether the Kenyan health care system can cope with the implementation of this package. The objectives of this study were to assess the $\mathrm{MOH}^{\prime} \mathrm{s}$ capacity to adapt focused ANC at the service delivery level so that it can be sustained, and to examine the extent to which adaptation of the package has increased coverage and quality of key ANC services and the overall quality of care received by pregnant women.

The study was conducted in two intervention districts (Busia and Lugari) and one comparison district (Siaya) using policy analysis and a situation analysis. For the policy analysis, data were collected through a desk review of current policy and service provider ANC guidelines, key informant interviews with stakeholders at the national and district levels, and focus group discussions with service providers and clients. For the situation analysis, data were collected through an assessment of six health facilities in each district, interviews with 12 providers, structured observations of client-provider interactions and exit interviews with 419 clients, and a review of ANC cards at the facilities. The key findings were as follows.

- The content of the focused ANC package in Kenya is comprehensive as recommended by WHO. Additional components were introduced to respond to national health needs. The new components include the prevention of mother to child transmission (PMTCT) of HIV, intermittent presumptive treatment (IPT) of malaria and developing an individual birth plan (IBP).

- Key stakeholders including health development partners are willing to support and implement focused ANC. Health development partners supported the initial piloting of the approach and continue to support the scaling-up of services. However, the support is fragmented - some partners support the whole package while others only support individual components.

- Inadequate staff training, shortage of equipment/supplies and inappropriate infrastructure inhibits provision of focused ANC services. Not all clinics offering focused ANC have staff trained in focused ANC. Clinics also lack the minimum logistics (in terms of equipment and supplies) and appropriate infrastructure to offer different components of focused ANC.

- Providers' capability to provide focused ANC is limited. Providers in clinics where focused ANC has been introduced have limited knowledge on certain aspects of focused ANC including timing of visits, PMTCT, and education and counselling for clients during visits. This reduces their capacity to provide services expected of them. 
- Introduction of focused ANC improved quality of care of specific ANC components. Quality of care for birth planning and potential complications, detection of existing diseases (e.g. malaria in pregnancy and STIs) and counselling on postpartum care did improve significantly in the intervention clinics. No effect was noted in quality of comprehensive history taking, education for prevention and promotion of health, and encouraging continuity.

- Clients are satisfied with all aspects of focused ANC except the waiting time and informal financial charges. Satisfaction ratings were consistently high in both intervention and comparison clinics for discussion of problems/concerns, explanations given by providers, quality of examination and treatment facility cleanliness, and treatment by clinic staff. Over half the clients in the intervention clinics were dissatisfied with waiting time for all four visits. Clients also complained about informal charges/fees on ANC services.

- Timing of ANC visits remains unchanged. A very small proportion of clients made their four ANC visits at the time expected for the focused ANC schedule.

- Planning was not sufficiently consultative. While an attempt was made to involve a wide range of stakeholders, some actors (e.g. pre-service training institutions and professional bodies) were either left out or brought on board at a later stage in the process.

- Sustainability is contingent upon overcoming both contextual and programmatic constraints. Focused ANC services throughout the country are largely dependent on support from health development partners, but segmentation by health development partners at the programmatic level has led to fragmentation of service delivery. Addressing the contextual and programmatic constraints would go a long way to creating a suitable environment for the sustainability of the approach.

In conclusion, focused ANC is acceptable to both clients and providers. The approach has also received tremendous support from both the government and health development partners. However, the sustainability of the focused ANC package is contingent upon availability of funding, availability of a minimum level of equipment and supplies, competent providers and a clear policy direction. The study recommends:

- Further consultation with key actors (such as pre-service training institutions and professional bodies) to ensure institutionalization and standardization of focused ANC.

- Community mobilization to create awareness about the new services being offered during ANC, such as birth planning and preparedness for complications, timing of ANC visits and the need to co-opt other critical actors, especially male partners, in preparation for birth and readiness for possible complications.

- Reorganizing ANC service delivery and client flow within clinics to reduce client-waiting time. 
- Training providers in the concept of focused ANC, with specific emphasis on scheduling of visits, continuity of provider for each client, incorporating PMTCT and developing an Individual Birth Plan (IBP) to respond to existing knowledge gaps. 


\subsection{Background}

An estimated 414 women per 100,000 live births die as a result of pregnancy related complications, childbirth and sequelae in the postnatal period, making maternal death the leading (27 percent) cause of death among women of the reproductive age. Moreover, the 2003 Kenya Demographic and Health Survey (KDHS) showed that over half of births in Kenya are delivered at home and without supervision of a health professional (nurse or midwife) (CBS et al 2004). Problems of malaria, anaemia, and STD/HIV/AIDS and TB have also contributed to the high maternal mortality ratio.

The risk of Plasmodium falciparam malaria that is associated with maternal anaemia and perinatal mortality is exceedingly high in some parts of the country, with a malaria parasitic prevalence of 45 percent in pregnant women (Parise et al 1998). It is also estimated that more than 6,000 primigravidae annually become severely anaemic due to malaria, and that approximately 4,000 infants annually are of low birth weight as a consequence of their mothers being infected with malaria during pregnancy. Almost 40 percent of all severe anaemia cases among first pregnancies are due to malaria (MOH 1998). The MOH developed National Guidelines for Diagnosis, Treatment and Prevention of Malaria (MOH 1997), which recommend the use of Sulfadoxine Pyrimethamine (SP) for intermittent presumptive treatment (IPT) of malaria in pregnancy. However, the KDHS 2003 shows that only 21 percent of women take drugs for malaria prevention during pregnancy, and an even smaller proportion (4\%) reported receiving IPT during an antenatal care visit. Studies in some districts report low knowledge and use of malaria prevention measures at the community and service delivery level. Moreover, only 40 percent of Kenyan women visit ANC clinics by the $24^{\text {th }}$ week of pregnancy thus delaying the start of malaria prevention and treatment. Most health workers are not aware that SP drugs are recommended during pregnancy and so are reluctant to administer them. Mothers report fear of miscarriage, congenital abnormalities, damage to the foetus, and side effects of sulphur-based drugs, which discourages them from using prophylactic medicines.

The prevalence of HIV infection among pregnant women is 7.3 percent (KDHS 2003), and an estimated 50,000 - 60,000 infants are infected with HIV annually due to mother-to-child-transmission ( $\mathrm{MOH} 2002)$. About 5-8 percent of the babies become infected with HIV during pregnancy through transmission across the placenta; while 10-20 percent become infected during labour and delivery; and another 10-15 percent become infected through breastfeeding. In responding to this, NASCOP has developed national evidence-based standards and guidelines for the antenatal management of HIV positive women and the Prevention of Mother to Child HIV/ AIDS transmission (PMTCT), intrapartum care, postpartum care and infant feeding and care $(\mathrm{MOH}, 2002)$. The guidelines are intended for use by health professionals and health institutions that provide ANC services.

The prevalence of Sexually Transmitted Infections (STIs) that are commonly associated with pregnancy-related problems such as abortion, macerated stillbirths and low birth weights is also high among pregnant women. A study that included 815 ANC clients found that 21 percent of them had at least one STI, including 
gonorrhoea, chlamydia, and trichomoniasis (Solo et al 1999). Syphilis prevalence in pregnant women ranges between 2 and13 percent (Valadez et al 1999; Temmerman et al 1999). To prevent and treat STIs in pregnancy, the National Guidelines for Quality Obstetrics and Perinatal Care (MOH 2002) recommend that all pregnant women should be screened and treated for STIs using the syndromic approach, and that all pregnant women are tested for syphilis and provided treatment if found seropositive. However, the 1999 Kenya Service Provision Assessment (KSPA) found that only 45 percent of clinics that offer STI services had the capacity to test for STIs, and fewer than 1 in 20 clinics had a constant stock of primary drugs used to treat the most common STIs (MOH et al 2000).

Birth spacing also threatens maternal health in Kenya. The 2003 KDHS showed a median birth interval of 32.6 months, which is lower than the minimum recommended birth interval of 36 months. Over half (59.4\%) of Kenyan children are born within less than 36 months after a previous birth. This situation reinforces the need during antenatal care to promote child spacing and use of family planning postpartum.

To promote the health and survival of mothers and babies, Kenya has adapted the WHO focused ANC package that promotes interventions that address the most prevalent health issues that affect mothers and newborns (Villar et al 2001). The major goal of focused ANC is to help women maintain normal pregnancies through:

- Targeted assessment to ensure normal progress of child bearing cycle and newborn period, and to facilitate the early detection of complications, chronic conditions, and other problems/potential problems that will affect the pregnancy;

- Individualized care to help maintain normal progress, including preventive measures, supportive care, health messages and counselling (including empowering women and families for effective self care), and birth preparedness and complication readiness planning.

For women whose pregnancies are progressing normally, WHO recommends a minimum of four ANC visits - ideally, at 16 weeks, 24-28 weeks, 32 weeks and 36 weeks. Each visit should include care that is appropriate to the overall condition and stage of pregnancy and should include:

- Identification of pre-existing health conditions,

- Early detection of complications arising during pregnancy,

- Health promotion and disease prevention, and

- $\quad$ Birth preparedness and complication planning. 


\subsection{Problem Statement}

While Kenya has adapted the WHO focused ANC package, it is debatable whether the Kenya health care system, which already has well documented weaknesses (see $\mathrm{MOH}$ et al 2000, MOH 2005), can cope with the requirements of reorganizing ANC services so that they are offered according to the WHO model. In South Africa, for example, which has the best-resourced health program in sub-Saharan Africa, although introduction of the package was feasible and acceptable, several factors, notably trainer and staff turnover, inadequate logistics and budgetary planning, and insufficient involvement of key stakeholders negatively affected clinic capacity to implement and sustain the re-organized services as well the quality of service provision (Chege et al 2005).

The WHO focused ANC package was introduced on a pilot basis in Kenya in 2001, but its acceptability among service providers and clients, the content and coverage of services, and the sustainability of the approach are not well understood. Even less is known about community awareness of focused ANC and whether quality of care and utilization patterns for ANC have been influenced as such. This study addressed the following questions:

- What contextual and process issues have influenced the feasibility and acceptability of the focused ANC package?

- Is focused ANC acceptable to the clients and providers?

- What is the actual content and coverage of focused ANC and are different components being provided as a package at the service delivery level?

- What is the level of quality of care being offered to pregnant women under the focused ANC package?

- Can the health care system sustainably deliver a focused ANC package?

\subsection{Methodology}

An integrated case study design was used, involving both a policy and situation analysis. The study was conducted at the national, district and facility levels. Two intervention districts, Busia and Lugari, exposed to focused ANC and one comparison district (Siaya), that was yet to be exposed to focused ANC, were included in the study.

Initially, Busia and Kilifi, which were the first two districts in Kenya in which the model was pilot-tested, were selected for the study. However, Kilifi was dropped due to an outbreak of famine in July 2004, which kept many pregnant women away from health facilities. Instead, Lugari district, where focused ANC was introduced in 2003 as a component of the Safe Motherhood Demonstration Project (SMDP), was selected as a replacement. Siaya district, with almost similar health infrastructure and disease prevalence as the two intervention districts, was selected as the comparison site. 


\section{Policy analysis}

The conceptual model developed by Walt and Gilson (1994) for analyzing health policy development and program implementation was applied retrospectively. Their model identifies and examines factors that have affected, or will affect, implementation of a new or revised policy/program and circumstances that have influenced its outcome. The model takes into account the program content, the actors involved, the processes contingent on developing and implementing change, as well as the context within which changes are introduced. Data were gathered through a desk appraisal, stakeholder appraisal and focused group discussions.

Desk appraisal: A desk review of current materials for orienting service providers for focused ANC was undertaken to determine the content and the extent to which they facilitated or influenced the provision of focused ANC at the service delivery level. In addition, district health plans, annual and quarterly reports were reviewed for their intentions to translate focused ANC into actual activities.

Stakeholder appraisal: Key informant interviews were held with 19 stakeholders at the national level and in the intervention districts, drawn from Ministry departments, private organizations, NGOs, health development partners, technical assistance agencies, professional associations, and training institutions. All individuals had, in one way or another, been involved in the formulation, promotion and implementation of focused ANC. The interviews focused on: the content of focused ANC, contextual issues, such as the circumstances under which focused ANC package was introduced, and the process through which focused ANC was formulated and introduced.

FGDS: Opinions, attitudes, knowledge and perceptions of the benefits of offering focused ANC were elicited through nine focus group discussion (FGDs) comprising 6-10 participants (see Table 1) from providers

\begin{tabular}{|l|l|}
\hline \multicolumn{2}{|l|}{ Table 1: Categorization of Focus Group Discussions } \\
\hline District & Category \& Number of FGD \\
\hline Busia & $\begin{array}{l}\text { Service providers (1) } \\
\text { Women who gave birth in the past year (1) } \\
\text { Pregnant women attending ANC (2) }\end{array}$ \\
\hline Lugari & $\begin{array}{l}\text { Service providers (1) } \\
\text { Women who have given birth in the past year (2) } \\
\text { Pregnant women attending ANC (2) }\end{array}$ \\
\hline
\end{tabular}
and clients in the two intervention districts. The service providers were mobilized through the District Medical Officer of Health. Given staff shortages, it was only feasible to conduct one FGD for each district. Key issues discussed related to how focused ANC was introduced, provider concerns and satisfaction with the process and package, perceptions of quality of care, preparedness of the health service delivery system and sustainability of the approach. FGDs with clients were difficult to organize due to competing time demands for women; participants were mainly recruited from women as they left ANC services.

\section{Situation Analysis}

A situation analysis was undertaken in one district hospital, four public health centres and one public dispensary in both intervention and comparison districts. Data were 
gathered through a facility assessment, provider interviews, and structured observations of client-provider interactions, exit interviews and ANC card reviews.

Facility assessment: Interviews were conducted with the clinic in-charge at the 12 intervention clinics and 6 comparison clinics to determine availability of infrastructure, equipment and supplies. A nurse working as a research assistant spent half a day at each clinic completing the clinic inventory.

Provider interviews: Short structured interviews with 12 providers assessed their training, knowledge of focused ANC, attitudes toward and satisfaction with the package. The interviews targeted ANC service providers in the intervention clinics who had received orientation on focused ANC.

Structured observations of client-provider interactions: Trained nurses observed and recorded on a standardized checklist all aspects of antenatal consultations to measure provider competence and their ability to follow service provider guidelines for focused ANC. Client-provider interactions were observed for four groups of ANC clients, one for each of the recommended four ANC visits. To reach a meaningful measure of quality of care with a relatively small sample size, six client-provider interactions were observed for each category at each clinic. A total of 419 clientprovider interactions (out of a proposed sample size of 432) were observed; 276 (out of 288 ) in the intervention clinics and 143 (out of 144) in the comparison clinics. The desired numbers were not achieved because of small numbers of clients attending for the fourth visit.

Client exit interviews: Short exit interviews were held with each consenting client after the consultation had been observed to ascertain their perceptions of the competence of providers and their overall impression of the service received. All 419 clients agreed to the exit interview.

Review of client ANC cards: At the first registration for ANC, clients are provided with ANC cards that they are expected to carry along during subsequent visits. At the point of exit, 30 consecutive ANC clients (including those that had been observed) were asked by an interviewer to review the card to determine timing of ANC visit and different ANC services performed and/or received. Altogether 527 (out of a planned 540) card reviews were made: 348 in the intervention clinics and 179 in the comparison clinics.

\subsection{Findings}

The findings are presented as follows: an analysis of the content of focused ANC; the context for implementation of focused ANC; the process of stimulating changes needed for the new approach; clinic preparedness to offer focused ANC; provider and client awareness of focused ANC services; clinic performance and quality of care under focused ANC; and provider and client satisfaction with focused ANC. 


\subsection{Recommended content of focused ANC in Kenya}

The Kenyan model of focused ANC was developed using the WHO model and inputs from the $\mathrm{MOH}$, especially the first Kenyan National Health Sector Strategic plan (1999-2004) which made malaria a high priority for prevention and treatment. The purpose of focused ANC in Kenya was described as:

- Achieving a good outcome for the mother and baby by preventing any complications that may occur in pregnancy, labour, delivery and postpartum; and

- Promoting timely and appropriate care for women during pregnancy to facilitate a healthy, positive outcome for mother and baby.

The recommended package targeted improvement in the content and quality of existing ANC services, and especially for intermittent presumptive treatment and case management of malaria, and also introduced new services. The package consists of:

- Care from a competent provider and continuity of care;

- Preparation for birth and potential complications;

- Health promotion and disease prevention: promotion of tetanus toxoid vaccination, nutritional supplementation, control of tobacco and alcohol use, prevention of malaria, among others;

- Detection of existing diseases and management of complications: severe anaemia, bleeding during pregnancy, severe oedema, malaria, hypertension, diabetes, tuberculosis, hepatitis and rheumatic fever, HIV/AIDS, foetal malpresentation after the $36^{\text {th }}$ week, abnormal foetal activity, foetal movement, syphilis and other STDs, especially genital ulcer disease; and

- Health education and counselling on: danger signs in pregnancy, nutrition and hydration, breastfeeding, sexually transmitted infections (STI), malaria and worm infestation, alcohol and tobacco, family planning practices, and an individual birth plan.

In addition, whereas the existing ANC schedule expected pregnant women to make 12 - 13 ANC visits (on a monthly basis to the $28^{\text {th }}$ week, then fortnightly to the $36^{\text {th }}$ week, then weekly until the $40^{\text {th }}$ week or birth), the focused ANC guidelines recommend that a pregnant woman should have four comprehensive, personalized ANC visits that include a package of quality services specifically tailored to the timing of each visit (MOH 2002; MOH-DOH/DOMC/JHPIEGO 2002). The guidelines also emphasize that each visit should consist of a different combination of services appropriate to the timing, as described in Annex 1.

\subsubsection{Actual content of focused ANC offered service delivery level}

The content of focused ANC, defined as the proportion of intervention clinics that are able to offer the full range of services recommended under the focused ANC package, was measured using data collected through the clinic inventory and provider interviews (see Table 2 ). While most intervention clinics routinely provided all 
requisite services for focused $A N C$, some essential services were not offered in a few clinics (Table 2), primarily PMTCT, TB screening and some tests. Family planning services were offered daily in all clinics, but it was not clear whether counselling on postpartum family planning was routinely included in ANC.

ANC services were provided daily in all intervention clinics. However, the introduction of focused ANC was not accompanied with a reorganization of ANC services. Service delivery continues to follow the "assembly line" format where clients have to go through several access points during a single visit including:

- Reception for cards to be stamped and numbered;

- Weighing;

- Consultation room (for history taking, consultation, examination and IPT, IBP, TT, as may apply);

- Depending on the outcome of consultation and number of visits, clients may be sent to the laboratory (located outside the clinic) or for PMTCT/VCT counselling (either within the ANC clinic or outside); and Pharmacy to collect medication (iron, folic acid, etc).

The sequencing of services varies across clinics, but on average clients

\begin{tabular}{|l|c|}
\hline \multicolumn{2}{|c|}{$\begin{array}{c}\text { Table 2: Focused ANC services routinely offered in } \\
\text { intervention clinics }\end{array}$} \\
\hline Services & $\mathrm{N}=12$ \\
\hline Weighing client & 12 \\
\hline Taking blood pressure & 12 \\
\hline Tetanus toxoid vaccination & 12 \\
\hline Preventive anti-malarial medication & 12 \\
\hline Counseling for family planning & 12 \\
\hline Treatment of STI & 12 \\
\hline Blood test for syphilis & 11 \\
\hline $\begin{array}{l}\text { Counseling on birth plan and emergency } \\
\text { preparedness }\end{array}$ & 11 \\
\hline VCT for HIV/AIDS & 10 \\
\hline Blood test for anemia & 10 \\
\hline Urine test for protein sugar and acetone & 10 \\
\hline PMTCT & 9 \\
\hline TB screening and detection & 0 \\
\hline
\end{tabular}
make a minimum of five contacts on a single visit, whereas the focused ANC expects that a woman will receive individualized/personalized care, primarily from one provider, consistently over the four visits.

\subsection{Context for introduction of focused ANC}

Focused ANC was introduced in a context in which many critical ANC services were not being widely offered, such as monitoring the progress of a pregnancy, identifying complications, referring mothers for specialized care at an appropriate time, and promoting postpartum family planning. Women presenting for ANC were likely to wait until the second trimester for their first visit, and a substantial proportion presented only in the third trimester, when it was too late to identify potential complicating conditions (e.g. malaria, STI/HIV, anaemia) and to prevent and/or manage them in time. By the start of the sixth month of pregnancy, 40 percent of Kenyan women had not made a single ANC visit. The median duration of gestation at which the first ANC visit was made was 5.7 months. An estimated 6 percent of the women did not make a single ANC visit at all (KDHS 1998). 
The 1999 Kenya Service Provision Assessment (KSPA) ${ }^{1}$ found that, nationally:

- Facilities experienced stock-outs of some critical prophylactic medicines such as ferrous sulphate, tetanus toxoid, anti-malarial drugs and antibiotics. As a result only 35 percent of clients were given iron prophylaxis despite the $\mathrm{MOH}$ policy to dispense iron to all pregnant women.

- Less than half of all clinics and health centres and a very small proportion of dispensaries had the testing and screening capacity for the six most important tests in ANC - pregnancy, urinalysis, blood glucose, malaria, syphilis, and HIV.

- Blood pressure was not taken in 40 percent of interactions.

- Routine history taking from clients was not comprehensive - many providers failed to ask clients their age, date of last menstrual period, experience of induced abortions or still births.

- Pregnant women were not properly counselled during ANC visits - among women attending ANC for the first time, close to half were not given the opportunity to ask questions, only a third were counselled about diet and one quarter were encouraged to deliver with a skilled attendant. Less than a quarter of the providers discussed warning signs such as excessive tiredness, vaginal bleeding, or fever. Use of family planning postpartum was hardly mentioned (only 10 times in 232 observed interactions). These issues were also rarely discussed in subsequent visits.

Kenya's per capita health spending was US\$21 in 1998 and has reduced to US\$19.20 currently (with 30 percent coming from Government sources, 54 percent private and 16 percent donors). A recent study on the costing of the safe motherhood program (Nganda 2003) showed that the MOH currently spends approximately KES 54 (US $\$ 0.70$ ) per capita on safe motherhood and well baby interventions. The study also reported that a considerable proportion of Government funding is used to pay staff wages and salaries, implying that the Government relies on external support from donors and health development partners to cover the cost of services. Over reliance on external support raises questions of the sustainability of the safe motherhood program, including focused ANC. As one program manager explained:

"The government is like an indigenous cow which produces very little milk though it can survive in the local environment and donors are like the exotic cow that produces more milk but usually dies as it can not withstand the local conditions" (Key informant interviews, Busia)

The health care system is also characterized by shortage of staff and lack of supportive supervision due to a freeze on hiring new staff, migration of staff to other countries, and non-replacement following death and retirement. While the government gave the $\mathrm{MOH}$ a go-ahead to hire new staff in 2004, the number allowed did not meet the needs on the ground (Personal communication with MOH Officials).

1 The 1999 KSPA was conducted at a representative sample of 388 health facilities throughout Kenya. A second KSPA was undertaken in 2004 but the results were not available at the time of this study. 
Moreover, reproductive health interventions, including focused ANC, have been introduced in the absence of a reproductive health policy ${ }^{2}$, implemented instead within the framework of the Kenya National Reproductive Health Strategy (19972010). The strategy was Kenya' s first step towards operationalizing the reproductive health principles endorsed at the 1994 Cairo conference, and addresses the following components (among others): promoting the concept of reproductive health; meeting family planning unmet needs; safe motherhood and child survival; and management of Sexually Transmitted Diseases (STDs) / HIV / AIDS. The strategy put in place a National Reproductive Health Program that sought to expand on the achievements of the $\mathrm{MCH} / \mathrm{FP}$ program that had been functioning since 1967. The goal of the program is to provide a comprehensive and integrated system of reproductive health care that offers a full range of services by the Government, NGOs and the Private Sector.

There are currently no standards and guidelines for implementing focused ANC. Instead, stakeholders, including service providers, refer to the orientation package developed by the MOH-DRH/DOMC/JHPIEGO for the pilot introduction project. Separate service standards and guidelines exist for PMTCT, malaria, STIs, and TB that are expected to guide the delivery of these services within an ANC consultation. Thus, the focused ANC package was introduced within a context in which there was little clear guidance on how to offer an integrated set of services and within a four-visit model.

\subsection{Process of stimulating changes in ANC}

Two technical assistance agencies - JHPIEGO and WHO/Kenya - played a key role in influencing the MOH's decision to embrace focused ANC. Following evidence of success from other countries, they proposed the idea of focused ANC to the MOH. JHPIEGO played the facilitative role of integrating the MOH's inputs with the original WHO focused ANC model, resulting in a service package called "Focused ANC and Malaria in Pregnancy." A particular focus on malaria control was included because it was felt that insufficient work had been done to address this serious problem. Once the package had been formulated, three tools were piloted and used to update existing ANC services in the intervention districts (see Table 3 below).

In-service training of service providers was an essential component of the process of stimulating changes, which received immense support from JHPIEGO. Staff training began with the provincial health management teams (PHMTs), district health management teams (DHMTs), and finally the operational teams (providers) at service delivery points. Provincial and district reproductive health teams were trained as trainers, comprising of a gynaecologist, nursing officer, clinical officer, records officer, matron in the provincial hospital, in-charge $\mathrm{MCH}$, in-charge maternity unit, and MTC tutor. 
Community sensitization activities were undertaken, which initially involved short messages about focused ANC to pregnant mothers through morning microteaching sessions held at $\mathrm{MCH} / \mathrm{FP}$ clinics. The microteaching involved group health talks and individual messages given by providers before and during service delivery. This approach was found to be ineffective in sensitizing community members, as it only targeted clients who sought services at clinics. Consequently a community orientation manual was developed to sensitize communities about the key changes (for example, pregnant women would only be expected to visit the clinics for 4 comprehensive visits) and to enlist the support of opinion leaders, men and other members of the family during the pregnancy. Although community sensitization was done through public meetings (barazas) to communicate changes in the delivery of antenatal services, the FGDs suggest that coverage was limited to opinion leaders.

\begin{tabular}{|c|c|}
\hline Tools & Content \\
\hline $\begin{array}{l}\text { Service provider orientation } \\
\text { package }\end{array}$ & 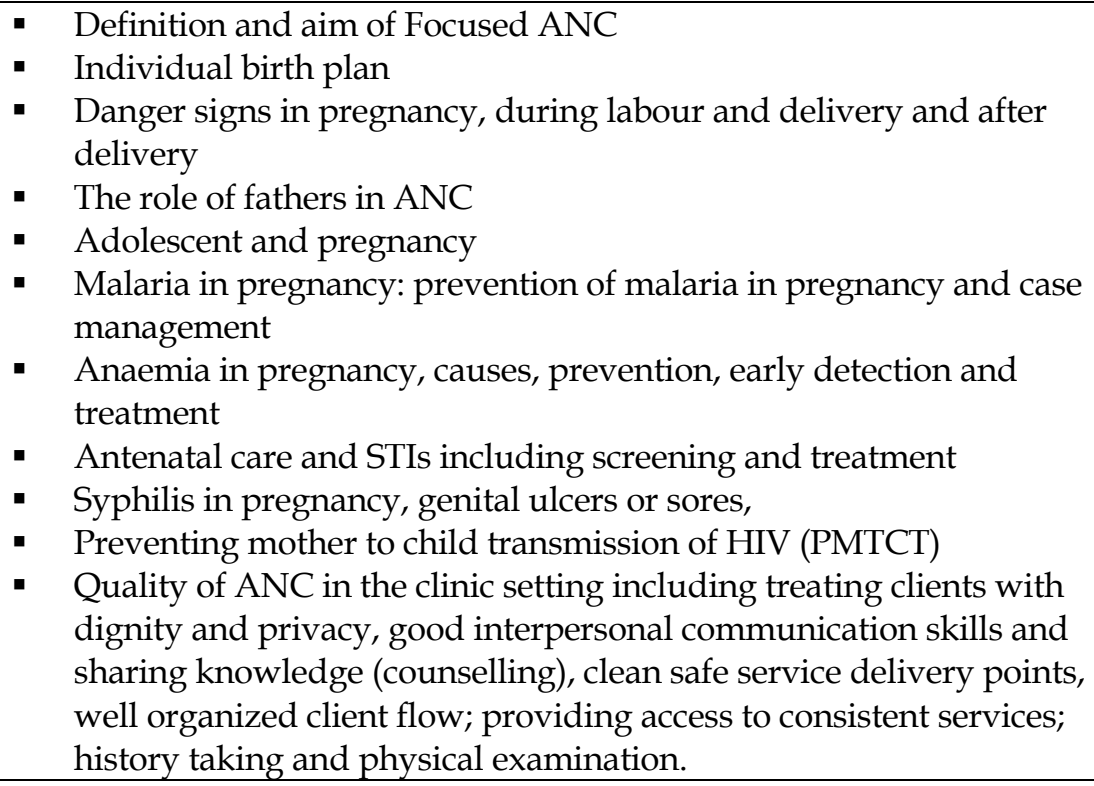 \\
\hline $\begin{array}{l}\text { Community orientation } \\
\text { package }\end{array}$ & $\begin{array}{l}\text { - } \quad \text { The importance of focused ANC } \\
\text { - } \quad \text { Danger signs in pregnancy and where to go for help } \\
\text { - The use of intermittent preventive treatment (IPT) in pregnancy } \\
\text { - The importance of health facility delivery with a skilled birth } \\
\text { attendant }\end{array}$ \\
\hline Job aid & $\begin{array}{l}\text { - } \quad \text { Focused ANC job aid } \\
\text { - } \quad \text { Malaria in pregnancy job aid } \\
\text { - } \quad \text { Coal oriented checklist } \\
\text { - } \quad \text { Father-to-be checklist } \\
\text { - } \quad \text { Individual Birth Plan (IBP) pamphlet } \\
\text { - }\end{array}$ \\
\hline
\end{tabular}


Research was part of the process of stimulating change. The $\mathrm{MOH}$, in collaboration with JHPIEGO and through DFID funding, first pilot tested a joint focused ANC and malaria in pregnancy intervention in 2001 in Kilifi and Busia districts, and subsequently replicated the intervention in 19 malaria endemic districts in 2002. Training materials on focused ANC and malaria in pregnancy for service providers and educational materials for the community were developed especially for this introduction. Service providers were up-dated on components of focused ANC, birth preparedness, danger signs, individualized birth planning and prevention and management of malaria in pregnancy.

JHPIEGO's technical support to the scale-up program activities included:

- Discussion and planning meeting at the central level held in Nairobi;

- Discussion and planning meetings held in three districts;

- Baseline/situational analysis carried out in four districts;

- Adaptation and adoption of training materials;

- Pre-test of training materials in one district;

- Reproduction of materials;

- Three training of trainers workshops for district MOH staff held in three districts;

- One training of trainers workshop held for central level MOH staff;

- An average of two meetings to disseminate focused ANC and the National Malaria Control Guidelines in 19 districts;

- Supporting supervision activities in approximately 25 percent of the health clinics in 17 of the 19 program districts; and

- A follow up survey carried out in the four districts with the baseline survey.

In 2003, the DRH, together with the DOMC, and with technical support from JHPIEGO, carried out a follow-up survey in four malaria holo-endemic districts ${ }^{3}$ (from among the 19 scale-up districts) to assess the impact of the intervention on knowledge, attitudes and practices of service providers and pregnant women with regard to prevention and control of malaria during pregnancy and focused ANC 4 (MOH 2003). The proportion of women receiving IPT had increased from 66 to 78 percent, the proportion of women receiving iron and foliate increased from 56 to 59 percent, proportion of women making a birth plan increased from 48 to 53 percent, and women were more knowledgeable on preventative measures against malaria. Knowledge of the effects of malaria on pregnant women increased substantially

3 Bondo, Homa Bay, Taita-Taveta, and Kwale districts. Holo-endemic means that transmission occurs throughout the year.

4 Specifically, this survey asked clients about their knowledge and practices regarding malaria, their birth preparedness and their experiences during ANC visits, including travel and waiting time, information given by the service providers and the provision of IPT. Service providers were asked about their knowledge of malaria and its effects in pregnancy, their awareness of national guidelines and their practices towards clients, particularly the provision of IPT, during the ANC consultation. 
among providers and written guidelines for malaria and danger signs in pregnancy were well recognized.

\subsubsection{Involvement of different actors}

Although departments other than the DRH and DOMC, including NASCOP, were not involved initially, they have since been co-opted. For instance, NASCOP's PMTCT activities, which used to be offered as a stand-alone service, have been integrated into focused ANC services. District reproductive health teams were involved in planning the implementation process ${ }^{5}$. The DHMT prepared their clinics for implementation of focused ANC through training health workers and ensuring that the minimum basic infrastructure was put in place.

In the absence of Government funding for short-term training, the scaling-up of focused ANC would have been difficult if such support was not forthcoming from health development partners, as described in Table 4. District health teams pointed out that there is a growing interest from health development partners to increase their support for focused ANC, and a number of NGOs (e.g., CHAK and Marie Stopes) have expressed their willingness to supplement Government efforts through providing basic equipment and essential drugs. In Busia district, the initial piloting was supported by JHPIEGO through DFID funding while SIDA has continued to support activities in the district through their health sector reform initiative. The district has also received training support from AMKENI (funded by USAID) and the Population Council (funded by DFID). Focused ANC activities in Lugari District have mainly received support from the Population Council with DFID funding.

\begin{tabular}{|l|l|c|}
\hline & \multicolumn{1}{|c|}{ Table 4: Development partners and donors } & \multicolumn{1}{|c|}{ Activities } \\
\hline $\begin{array}{l}\text { Donor \& } \\
\text { project period }\end{array}$ & \multicolumn{1}{|c|}{ District } \\
\hline SIDA $2004-2005$ & $\begin{array}{l}\text { Sensitization of community leaders in } \\
\text { comprehensive RH } \\
\text { FANC equipment and supplies } \\
\text { Sensitization of community leaders on PMTCT } \\
\text { services } \\
\text { Malaria prevention/purchase of insecticides } \\
\text { Training PMTCT counsellors on rapid HIV testing }\end{array}$ & Busia \\
\hline $\begin{array}{l}\text { UNICEF } \\
\text { 2004-2005 }\end{array}$ & Malaria prevention and treatment & Busia \\
\hline $\begin{array}{l}\text { DARE (World } \\
\text { Bank) }\end{array}$ & $\begin{array}{l}\text { Malaria Prevention and treatment - training health } \\
\text { 2004-2005 }\end{array}$ & Borkers on malaria case management \\
HIV/AIDS prevention and management & Busia \\
\hline
\end{tabular}
district hospital, in-charge $\mathrm{MCH}$, in-charge maternity unit, and MTC tutor with the District Medical Officer of Health as chair and District AIDS Coordinator, District Nutritionist and Laboratory Technologists as additional members. 


\begin{tabular}{|l|l|c|}
\hline $\begin{array}{l}\text { AMKENI } \\
\text { (USAID) } \\
2004-2005\end{array}$ & $\begin{array}{l}\text { Training health workers on FANC and MIP } \\
\text { FANC equipment and supplies } \\
\text { Reproductive health activities - FP, VCT and } \\
\text { PMTCT } \\
\text { Establishment and training of district RH team }\end{array}$ & Lugari \\
\hline $\begin{array}{l}\text { MSF-S } \\
\text { 2004-2005 }\end{array}$ & $\begin{array}{l}\text { HIV/AIDS prevention and management - VCT } \\
\text { PMTCT, and ARVs }\end{array}$ & Busia \\
\hline $\begin{array}{l}\text { Population } \\
\text { Council } \\
\text { (DFID) } \\
\text { 2001-2003 }\end{array}$ & $\begin{array}{l}\text { Safe motherhood demonstration project - } \\
\text { incorporates FANC }\end{array}$ & Lugari \\
\hline
\end{tabular}

(Sources: District work plans and reports 2003/2004)

There is, however, a growing concern by district health teams that support from development partners is fragmented because their support is only for specific districts, specific ANC components and for a limited period of time. No single donor is supporting focused ANC as a comprehensive package. It is also evident that some components (e.g., PMTCT and malaria) attract more funding than others, which further fragments implementation. The challenge is for the DRH to coordinate the external support it receives from different donors specifically for ANC services with its core support from the treasury; it is anticipated that this coordination will be addressed through the emerging Sector Wide Approach (SWAp) that Kenya is currently pursuing.

The planning process for the implementation of focused ANC was not fully consultative. The initial development stage involved the DRH and DOMC, Department of Obstetric and Gynaecology, University of Nairobi, Division of Nursing, Regional Obstetrician and Gynaecologists, JHPIEGO staff, and the Kilifi District health staff. NASCOP was brought on board at a later stage, while the National TB program, pre-service training institutions and professional bodies were not initially consulted. The professional groups (e.g. Kenya Medical Association, Nursing Association and Midwifery Chapter of Kenya) were neither consulted during the formulation of focused ANC nor involved in the government's decision to embrace the approach.

Due to their non-involvement in the planning phase, the training curricula of pre-service training institutions and supervision guidelines of professional bodies have not been updated to reflect the change of approach. Although a common curriculum for preservice training institutions is in preparation, it has yet to be finalized, and so recent graduates

\begin{tabular}{|l|c|c|}
\hline \multicolumn{3}{|c|}{ Table 5: Mean clinic preparedness score by site } \\
\hline \multicolumn{1}{|c|}{ Availability of: } & $\begin{array}{c}\text { Intervention } \\
\text { Clinics } \\
\text { (N= 12) }\end{array}$ & $\begin{array}{c}\text { Comparison } \\
\text { Clinics } \\
\text { (N=6) }\end{array}$ \\
\hline $\begin{array}{l}\text { Essential ANC equipment } \\
\text { (Score 0-8) }\end{array}$ & 6.3 & 6.4 \\
\hline Infrastructure (Score 0-6) & 5.1 & 4.7 \\
\hline $\begin{array}{l}\text { Guidelines, protocol, IEC } \\
\text { material (score 0-8) }\end{array}$ & $4.8^{*}$ & $2.6^{*}$ \\
\hline $\begin{array}{l}\text { Essential ANC drugs } \\
\text { (Score 0-10) }\end{array}$ & 3.0 & 3.7 \\
\hline $\begin{array}{l}\text { Essential laboratory } \\
\text { supplies (Score 0-10) }\end{array}$ & 3.2 & 3.7 \\
\hline Total score (0-42) & 22.4 & 21.1 \\
\hline$* 0.05$ & & \\
\hline
\end{tabular}


may not be aware of the revised approach. TB is yet to be integrated in focused ANC service delivery.

\subsection{Clinic preparedness to offer focused ANC}

An index of clinic preparedness (Table 5) was constructed using five indicators:

- Availability of infrastructure (Score 0-6): ANC waiting area, private space for ANC counselling, private space for ANC examination, source of clean water, electricity and laboratory.

- Availability of guidelines, reference manuals, registers, forms and ANC cards on site (score 0-8): ANC register, standard guidelines/protocol for focused ANC, revised ANC cards, guidelines for PMTCT, guidelines for diagnosis treatment and prevention of malaria in pregnancy, focused ANC job aid, malaria in pregnancy job aid, and individual plan pamphlets.

- Availability of essential equipment (score 0-8): Blood pressure gauge, foetoscope, stethoscope, adult scale, measuring tape, thermometer, vaginal speculum (L, M, S), and gynaecological examination table.

- Availability of essential drugs (Score 0-10): Tetanus toxoid, Iron folic, ferrous sulphate, Sulfadoxine Pyrimethamine, contrimodaxizale, amoxycillin, benzathine penicillin/PPF, erythromycin, metronodazale (flayl), mebendazole.

- Availability of laboratory supplies (score 0-10): reagents for urine test for glucose and protein, VDRL/RPR for syphilis, Elisa for HIV-1, Elisa for HIV-2, HIV-rapid test, reagents for anaemia tests, pregnancy test, disposable gloves, urine specimen bottles.

Data were drawn from the clinic assessment tool and mean scores computed for each indicator, and then aggregated across all indicators to give the composite score for clinic preparedness, and compared across intervention and comparison clinics. Overall, there is no significant difference between the clinics, apart from availability of guidelines, protocols and IEC materials. Essential drugs and laboratory supplies were very low in all clinics. This suggests that introduction of focused ANC was not accompanied by strengthening clinic preparedness.

\subsection{Awareness of focused ANC package and services}

Table 6: Provider exposure to focused ANC

\begin{tabular}{|l|c|}
\hline Training received pre-service & $\mathrm{N}=12$ \\
\hline Management of delivery & 12 \\
\hline Antenatal care & 11 \\
\hline Postnatal care & 11 \\
\hline Family planning counseling & 10 \\
\hline $\begin{array}{l}\text { Counseling/health education for maternity } \\
\text { clients }\end{array}$ & 10 \\
\hline Any contraceptive technology & 9 \\
\hline Exclusive breastfeeding & 9 \\
\hline STI Syndromic management \& treatment & 7 \\
\hline Postabortion care & 6 \\
\hline Counseling for prevention of STI & 6 \\
\hline $\begin{array}{l}\text { Medical Management of HIV/AIDS } \\
\text { infected clients }\end{array}$ & 5 \\
\hline Clinical diagnosis and treatment of STI & 5 \\
\hline PMTCT of HIV/AIDS & 4 \\
\hline $\begin{array}{l}\text { Anti-retroviral therapy for HIV/AIDS } \\
\text { infected clients }\end{array}$ & 4 \\
\hline Syphilis screening (RPR) test & 4 \\
\hline $\begin{array}{l}\text { Counseling/social support for HIV/AIDS } \\
\text { infected clients }\end{array}$ & 3 \\
\hline Orientation on focused ANC components & $\mathrm{N}=12$ \\
\hline Birth preparedness & 10 \\
\hline Malaria in pregnancy (IPT) & 9 \\
\hline VCT for HIV/AIDS & 9 \\
\hline $\begin{array}{l}\text { Elaborate physical examination of a } \\
\text { pregnant woman }\end{array}$ & 8 \\
\hline Anemia in pregnancy & 7 \\
\hline Elaborate history taking of pregnant woman & 7 \\
\hline Testing for HIV, VDRL & 4 \\
\hline PMTCT of HIV & \\
\hline
\end{tabular}




\subsubsection{Provider awareness of focused ANC}

Provider awareness of focused ANC was assessed through their exposure to focused ANC during pre and in-service training; and knowledge of different components of focused ANC (Table 6). The 12 providers interviewed had a range of technical qualifications including registered nurse with midwifery (2), registered nurse without midwifery (1), registered midwife (3), enrolled nurse (3) and nursing aide/assistant (3).

About half of the providers did not receive pre-service training on some key aspects of focused ANC, such as clinical diagnosis and treatment of STI, PMTCT and syphilis screening. Nearly all the clinics (10) reported that their staff had been trained specifically in focused ANC. At the time of the study, few staff had been trained in PMTCT, and PMTCT services were just beginning to be rolled out in Lugari and some clinics were yet to be covered.

Although nine clinics had copies of the Reproductive Health Service Delivery Standards Guidelines, only six providers had been oriented on their use. Nine clinics possessed the focused ANC and malaria in pregnancy orientation package manual and providers in these clinics reported having received a one-week

training/orientation on focused ANC. When asked how well they knew the focused ANC guidelines and standards, only two providers reported very well, eight reported fairly well, and two did not know the guidelines well.

Table 7 describes the providers' own rating of their level of knowledge of focused ANC components. The

\begin{tabular}{|l|c|c|}
\hline \multicolumn{3}{|c|}{$\begin{array}{c}\text { Table 8: Proportion of providers who are } \\
\text { knowledgeable about gestation age for } \\
\text { focused ANC visits }\end{array}$} \\
\hline Visit & Weeks & $\begin{array}{c}\text { Providers } \\
\text { N }=12\end{array}$ \\
\hline First & $0-16$ & 7 \\
& $8-18$ & 1 \\
& $16-24$ & 4 \\
& $12-20$ & 2 \\
\hline Second & $16-24$ & 5 \\
& $20-28$ & 3 \\
& $24-36$ & 2 \\
& $24-30$ & 4 \\
\hline Third & $24-34$ & 6 \\
& $32-34$ & 1 \\
& $36-38$ & 1 \\
& 34 & 1 \\
\hline Fourth & 36 & 7 \\
& 38 & 1 \\
& 40 & 3 \\
\hline
\end{tabular}

Table 7: Provider rating of their knowledge of focused ANC components

\begin{tabular}{|l|c|c|c|}
\hline \multicolumn{1}{|c|}{ Component } & None & Basic & Detailed \\
\hline $\begin{array}{l}\text { Individual Birth } \\
\text { Planning }\end{array}$ & 1 & 6 & 5 \\
\hline $\begin{array}{l}\text { Danger signs in } \\
\text { pregnancy }\end{array}$ & 0 & 2 & 9 \\
\hline $\begin{array}{l}\text { Danger signs during } \\
\text { labor, delivery \& after } \\
\text { delivery }\end{array}$ & 1 & 2 & 9 \\
\hline $\begin{array}{l}\text { The role of birth } \\
\text { partners during ANC }\end{array}$ & 2 & 8 & 2 \\
\hline Malaria in pregnancy & 0 & 2 & 10 \\
\hline Antenatal care \& STI & 0 & 5 & 7 \\
\hline PMCT of HIV & 4 & 6 & 2 \\
\hline VCT for HIV & 6 & 5 & 1 \\
\hline $\begin{array}{l}\text { Comprehensive } \\
\text { history taking }\end{array}$ & 0 & 1 & 11 \\
\hline
\end{tabular}

greatest areas of weakness were in PMTCT and VCT for HIV. Providers considered their knowledge of the role of birth partners during antenatal care and IBP as basic rather than detailed. When asked what they understood about the concept of focused ANC, nine providers gave appropriate answers, including reducing complications (5), clients making four visits 
for comprehensive care (1), and individualized ANC service provision (3). The other three providers did not know anything specific about focused ANC, apart from it being a service for pregnant mothers.

When asked about the least number of antenatal visits a woman should make during pregnancy, ten mentioned four times while two mentioned three and five times each. Most providers were aware of when the first ( $<16$ weeks) and the fourth (36 weeks) visits should be made (Table 8 ), but none mentioned precisely when the second (20-24 weeks) and third (28 - 32 weeks) visits should be made.

The overall knowledge score on components of focused ANC was 3.48 out of 6 (Table 9). Knowledge of malaria prevention in pregnancy was the highest. All providers mentioned counselling clients about use of treated bed nets and intermittent preventive treatment with SP, while only three mentioned case management of symptomatic women. All providers correctly mentioned SP-Fansidar as the recommended anti-malarial for use among pregnant women and when the first dose should be administered. Five providers did not know the stage in pregnancy when the

\begin{tabular}{|l|c|}
\hline \multicolumn{2}{|c|}{$\begin{array}{c}\text { Table 9: Provider knowledge mean score for } \\
\text { different focused ANC components }\end{array}$} \\
\hline & Mean Score \\
\hline $\begin{array}{l}\text { Prevention of malaria in } \\
\text { pregnancy }\end{array}$ & 0.78 \\
\hline $\begin{array}{l}\text { Detection \& prevention of } \\
\text { anemia in pregnancy }\end{array}$ & 0.52 \\
\hline Counseling on PMTCT & 0.40 \\
\hline $\begin{array}{l}\text { Counseling on individual birth } \\
\text { planning }\end{array}$ & 0.51 \\
\hline Management of syphilis & 0.75 \\
\hline Danger signs in pregnancy & 0.52 \\
\hline $\begin{array}{l}\text { Index score } \\
\text { (0 - 6) }\end{array}$ & $\mathbf{3 . 4 8}$ \\
\hline
\end{tabular}
second dose of SP should be administered.

Three quarters of the providers knew that all pregnant women should be tested for syphilis and that if found positive, they and their partner should be treated. When asked to name the four major causes of anaemia in pregnancy, all providers knew the relationship between iron deficiency, malaria and anaemia in pregnancy. However, only seven identified hookworms as another cause of anaemia in pregnancy. Knowledge of the relationship between advanced HIV/AIDS and anaemia was lacking; only one provider mentioned it. Most providers were not conversant with the different means for making a quick diagnosis of anaemia in pregnancy; providers mentioned laboratory and physical tests more frequently than direct questions to clients as ways of looking for signs and symptoms. Providers were aware of the need to give ferrous sulphate and folic acid and to counsel clients about eating a balanced diet as a prevention measure for anaemia. Although all providers identified malaria as a major cause of anaemia in pregnancy, half of them did not routinely give IPT.

Knowledge about PMTCT was poor. Most providers were not aware of the appropriate counselling information, and although more than half mentioned the need to undertake VCT and to determine the HIV status of the mother, most did not mention other relevant counselling issues. Provider knowledge of the kind of messages that should be given to HIV+ mothers to promote safer breastfeeding was also lacking. 
When asked about appropriate information to be given to the client on birth planning, most providers mentioned identification of a health facility for delivery, putting money aside in case of emergency, and collecting and preparing basic supplies for delivery. Crucial issues such as due date of delivery, identifying a decision maker in case of emergency, and having a birth partner were hardly mentioned.

Providers were not knowledgeable on all the danger signs in pregnancy. While nearly all knew about vaginal bleeding, only three mentioned laboured breathing and more than half did not know about premature labour pains, or the baby's movements.

\subsubsection{Client awareness of focused ANC}

Client's knowledge of changes in ANC and different components of focused ANC was assessed through FGDs, and client practices were assessed through ANC card reviews.

Knowledge of changes in ANC service delivery: The FGDs indicate that while some clients were not aware that there had been a shift from the traditional way of providing ANC services, most of them, and especially pregnant women, were well informed about the change. Clients who were reportedly unaware of the new approach claimed that they had not seen any changes in the way they were being handled. A client explained:

"Even if there is a new approach, I still do not see any differences." (FGD Participant, Lugari)

Conversely, clients who reported awareness of the new approach cited a number of changes in the delivery of ANC services in their clinics, including extensive laboratory tests, VCT services for HIV/AIDS, malaria prevention and treatment through IPT and provision of bed nets to pregnant mothers at a cheaper price, increased number of injections for immunization and early diagnosis of danger signs. This was well captured in the following comment from women who had given birth in the past year:

"We are now treated for malaria as we get other services. We are given malaria tablets to take even before we leave this facility. I think this is to make sure we take them (1 ${ }^{\text {st }}$ participant). $2^{\text {nd }}$ participant (interjects), there is change, these days we are advised to deliver in hospital and we also undergo numerous laboratory tests. $3^{\text {rd }}$ participant, we are tested on HIV/AIDS and in case infected you are given medication and advised." (Client FGD, Busia)

Even some of the women who had never attended ANC services were aware of the existence of a new approach and reported these changes, especially VCT and IPT, having learnt about the change from the media and other women who attended ANC clinics. One woman reported: 
"...I first knew it through a radio broadcast programme, it was said that the new approach ensures that pregnant women are counselled and tested for HIV/AIDS." (Client FGD, Busia)

Another woman stated:

"... I have always heard about it from some mothers. They say it provides them with immunization through injections." (Client FGD, Busia)

The most common source of information about the new approach was through micro teaching sessions conducted every morning at health clinics; some clients got to know of the change through the new antenatal card.

Knowledge of components of focused ANC: While most participants were aware of the change in approach in the delivery of ANC, their knowledge of the components of focused ANC was limited, with the exception of malaria; nearly all clients knew about malaria prevention during pregnancy, reporting use of anti malarial drugs, sleeping under a treated bed net, and the need for a well-drained environment without bushes. IPT using SP and administered as DOTS was mentioned as a good prophylactic measure, although concerns were raised about growing parasite resistance to SP.

None of the participants in any FGDs knew that they were only required to make four visits; most reported that they were still required to make monthly visits.

Knowledge of PMTCT was equally limited. Those participants who had heard about PMTCT knew about it through the morning micro teaching sessions and a radio broadcast program (Kipindi cha tembea na majira). Participants in Busia were better

Table 10: Clients' timing of visits as recorded on ANC card

\begin{tabular}{|c|c|c|}
\hline $\begin{array}{c}\text { Gestation } \\
\text { Age (Weeks) }\end{array}$ & $\begin{array}{c}\text { Intervention } \\
\text { clinics (\%) }\end{array}$ & $\begin{array}{c}\text { Comparison } \\
\text { clinics (\%) }\end{array}$ \\
\hline $1^{\text {st }}$ visit & $\mathrm{N}=344$ & $\mathrm{~N}=178$ \\
\hline$<16$ & 9 & 4 \\
\hline $16-19$ & 7 & 10 \\
\hline $20-24$ & 42 & 29 \\
\hline $25-27$ & 9 & 8 \\
\hline $28-32$ & 26 & 34 \\
\hline $33-35$ & 5 & 7 \\
\hline $36 \&$ above & 2.9 & 8 \\
\hline $2^{\text {nd }}$ visit & $\mathrm{N}=\mathbf{2 5 0}$ & $\mathrm{N}=134$ \\
\hline$<20$ & 4 & 0.7 \\
\hline $20-24$ & 16 & 16 \\
\hline $25-27$ & 15 & 6 \\
\hline $28-32$ & 42 & 44 \\
\hline $33-35$ & 9 & 16 \\
\hline $36 \&$ above & 12 & 17 \\
\hline $3^{\text {rd }}$ Visit & $\mathrm{N}=149$ & $\mathrm{~N}=86$ \\
\hline$<28$ & 7 & 8 \\
\hline $28-32$ & 40 & 36 \\
\hline $33-35$ & 19 & 20 \\
\hline $36 \&$ above & 34 & 36 \\
\hline $4^{\text {th }}$ visit & $N=65$ & $\mathrm{~N}=41$ \\
\hline$<36$ & 40 & 42 \\
\hline 36 & 18 & 29 \\
\hline$>36$ & 42 & 29 \\
\hline
\end{tabular}
informed about PMTCT than those in Lugari.

A few participants were aware of the need for an IBP, but their knowledge was not comprehensive. They reported having been advised to keep money for transport and delivery and to buy supplies such as gloves and cotton wool in advance. Clientprovider interactions also confirmed that these aspects were mentioned during 
consultations. Other aspects such as involving a birth partner and arranging for a delivery place were not mentioned.

Timing of ANC visits: Through a review of ANC client cards, comparisons were made between intervention and comparison clinics to determine whether clients were making their ANC visits according to the new schedule; 1,247 cards were reviewed. Table 10 shows that the timing of ANC visits was not significantly different between intervention and comparison clinics.

\subsection{Quality of care under focused ANC}

Quality of care was measured using a scale aggregating scores from indicators of five key components of focused ANC: comprehensive history taking; detection of existing diseases and management of complications; prevention of disease and promotion of health; planning for birth and prevention of complications; and postpartum care including encouraging continuity of care. The scores were generated from observations of client-provider interactions during the ANC visits, and a mean score computed for each component and for each visit; these were then compared using statistical significance tests between intervention and comparison clinics.

\begin{tabular}{|c|c|c|c|c|c|c|c|c|}
\hline \multicolumn{9}{|c|}{ Table 11: Quality of care } \\
\hline & \multicolumn{4}{|c|}{ Intervention Clinics } & \multicolumn{4}{|c|}{ Comparison Clinics } \\
\hline Indicators & $\begin{array}{c}\mathrm{V}_{1} \\
\text { Score }=0-\end{array}$ & $\begin{array}{c}\mathrm{V}_{2} \\
\text { Sore }=0-\end{array}$ & $\begin{array}{c}\mathrm{V}_{3} \\
\text { Score }=0-\end{array}$ & $\begin{array}{c}\mathrm{V}_{4} \\
\text { Score }=0-\end{array}$ & $\begin{array}{c}\mathrm{V}_{1} \\
\text { Score }=0-\end{array}$ & $\begin{array}{c}V_{2} \\
\text { Score }=0-\end{array}$ & $\begin{array}{c}\mathrm{V}_{3} \\
\text { Score }=0-\end{array}$ & $\begin{array}{c}\mathrm{V}_{4} \\
\text { Score = 0- }\end{array}$ \\
\hline Comprehensive history taking & .363 & - & - & - & .330 & - & - & - \\
\hline $\begin{array}{l}\text { Detection of diseases and } \\
\text { management of complications }\end{array}$ & $.504^{* *}$ & $.670^{*}$ & .603 & .397 & $.339^{* *}$ & $.535^{*}$ & .571 & .395 \\
\hline $\begin{array}{l}\text { Prevention of disease and } \\
\text { promotion of health }\end{array}$ & 247 & 189 & 120 & .104 & .314 & 182 & 116 & 110 \\
\hline $\begin{array}{l}\text { Preparation for birth \& } \\
\text { potential complications }\end{array}$ & $.240^{\star *}$ & $.261^{* *}$ & $.275^{\star *}$ & $.0581^{\text {** }}$ & $.035^{* *}$ & $.035^{* *}$ & $.053^{* *}$ & $.064^{* *}$ \\
\hline $\begin{array}{l}\text { Counselling on Postpartum } \\
\text { care }\end{array}$ & - & - & $.042^{* *}$ & $.031^{*}$ & - & - & $.000^{* *}$ & $.000^{*}$ \\
\hline Encouraging continuity of care & .691 & .658 & .672 & .671 & .639 & 0642 & .629 & .618 \\
\hline Total performance & $2.045^{\star *}$ & $1.779^{* *}$ & $1.711^{* *}$ & $1.261^{* *}$ & $1.657^{* *}$ & $1.396^{* *}$ & $1.369^{* *}$ & $1.187^{* *}$ \\
\hline
\end{tabular}

Table 11 shows that introduction of focused ANC has had a positive effect overall on the quality of care. A highly significant effect is noted in detection of existing diseases in pregnancy during the first ANC visit, planning for birth and prevention of complications and counselling for postpartum care. No effect was found, however, in comprehensive history taking, prevention and promotion of disease, and consultation to encourage continuity in care.

\subsubsection{Comprehensive history taking}

Providers are expected to record a client's personal, family, social, current and previous pregnancy history during the first visit. A client's contraceptive history, medication currently being taken, alcohol use and smoking, HIV status and general 
health problems, and complaints (danger signs) in the current pregnancy should also be determined. In none of 72 first visit consultations observed in the intervention clinics did providers take a comprehensive personal, family and social history of clients. In all cases, providers recorded some elements while ignoring others, so that all clients had partial histories taken, and there was no difference between the intervention and comparison clinics.

Full previous pregnancy history (date of last pregnancy, place of delivery, duration of labour, type of delivery, any previous still birth(s) and any heavy bleeding during or after delivery with a previous pregnancy) was taken in only one of 72 consultations, partially in most cases, and not at all in 10 percent in the intervention clinics. In the comparison clinics, pregnancy history was not taken in 17 percent of cases and partially taken in 83 percent cases. There was no significant difference between intervention and comparison clinics.

For focused ANC, history taking during the subsequent visits is not expected to be as comprehensive as that taken during the first visit. During the second visit, history taking includes asking clients about how they were feeling, medication currently taken, alcohol use and smoking, tetanus immunization (TT) and general health problems. In the third visit the providers were expected to ask about these general issues and enquire whether the client had taken the first dose of SP treatment to prevent malaria. During the fourth visit the providers were expected to record the client's history on general issues including medication being taken and alcohol use and smoking. Apart from taking clients history, providers were also expected to record pertinent information on the client's card and respond immediately to any urgent problems in all the visits.

None of the providers in both the intervention and comparison clinics took all the required information during the second, third and fourth visits; all clients had their histories taken partially. For example, during the second visit only 58 percent of clients were asked about TT immunization while first dose of SP was only asked about for 49 percent of third visit clients.

Figure 1: Proportion of providers who inquired about danger signs in pregnancy during ANC visits 


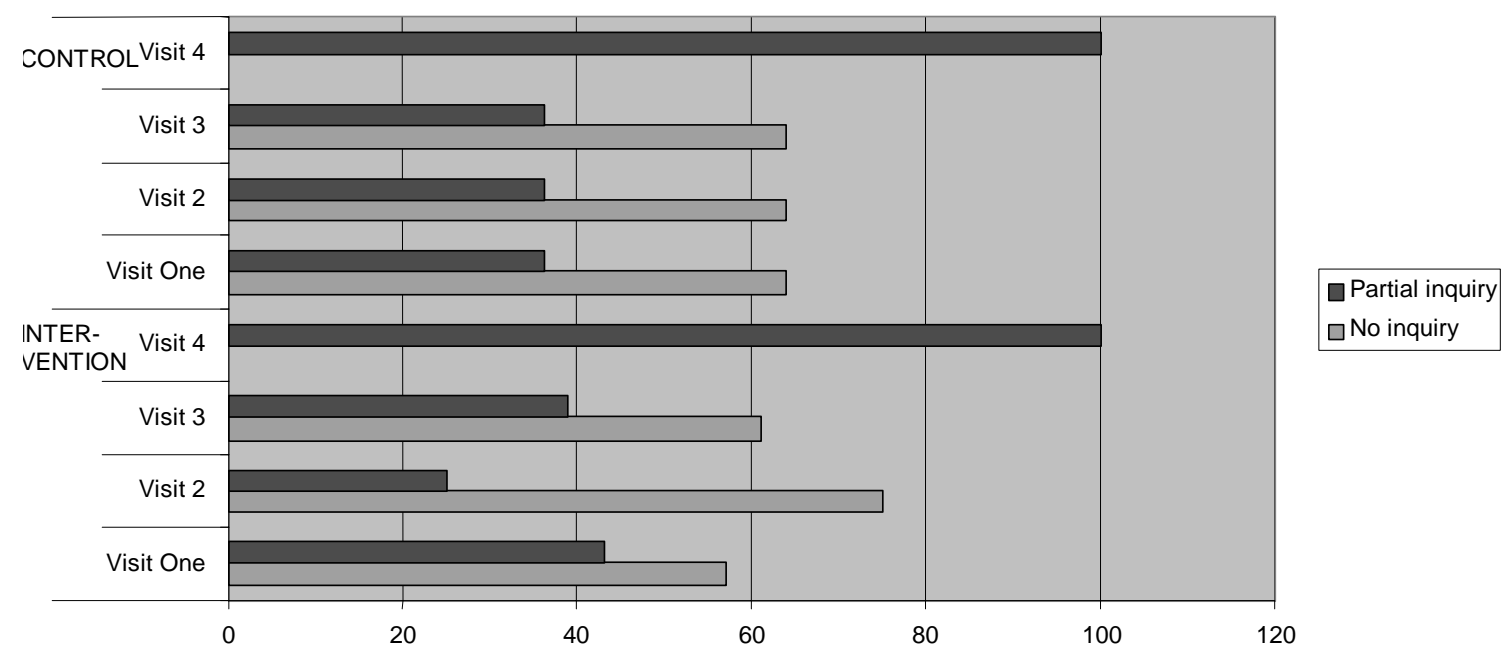

Observers recorded whether providers asked about specific issues related to danger signs in pregnancy such as bleeding, vaginal discharge, fever, headache/blurred vision, swollen face hands and legs, tiredness/ breathlessness and convulsions or fits during the first and second visits. In addition to these, providers were expected to find out whether clients had felt the baby move during the third visit and any premature labour pains (severe headache, lower abdominal pains) in the fourth visit. There was not a single case where a full inquiry was made into these issues during all the visits observed in both the intervention and comparison clinics (Figure 1). Providers did not inquire at all into the danger signs in pregnancy for 60 percent of clients in the intervention clinics during the first, second and third ANC visits. Providers in the comparison clinics also did not always inquire about dangers signs (64 percent) even though this is part of regular ANC.

Providers are also supposed to counsel clients about these danger signs, as well as to advise them about self-care, including the quality and quantity of food to eat during pregnancy, personal hygiene and rest/exercise during pregnancy. As seen in Table 12 , clients in both comparison and intervention clinics were rarely counselled on danger signs, with less than one quarter receiving counselling on self-care across all visits and sites.

\begin{tabular}{|l|c|c|c|c|c|c|c|c|}
\hline \multicolumn{1}{|c|}{ Table 12: Proportion of clients who received counselling on danger and self-care during pregnancy, by } \\
visit and site \\
\hline
\end{tabular}




\begin{tabular}{|l|c|c|c|c|c|c|c|c|}
\hline Vaginal bleeding & 11 & 7 & 8 & 10 & 0 & 6 & 0 & 0 \\
\hline Fever & 6 & 3 & 4 & 2 & 0 & 0 & 0 & 0 \\
\hline $\begin{array}{l}\text { Excessive tiredness } \\
\text { or breathless }\end{array}$ & 8 & 3 & 3 & 2 & 0 & 3 & 0 & 0 \\
\hline $\begin{array}{l}\text { Swollen hands, face, } \\
\text { legs }\end{array}$ & 8 & 13 & 4 & 3 & 0 & 36 & 0 & 0 \\
\hline $\begin{array}{l}\text { Severe headache or } \\
\text { blurred vision }\end{array}$ & 11 & 3 & 6 & 3 & 0 & 3 & 0 & 0 \\
\hline $\begin{array}{l}\text { Baby moving less or } \\
\text { not moving at all }\end{array}$ & - & - & 4 & 0 & - & - & 0 & 0 \\
\hline Convulsions or fits & - & 1 & 1 & 2 & - & 0 & 0 & 0 \\
\hline Premature labour & - & - & - & 8 & - & - & - & 3 \\
\hline $\begin{array}{l}\text { Discussed quality of } \\
\text { food to eat }\end{array}$ & 32 & 24 & 21 & 20 & 22 & 6 & 3 & 3 \\
\hline Discussed hygiene & 25 & 10 & 8 & 12 & 9 & 0 & 8 & 3 \\
\hline $\begin{array}{l}\text { Advised on rest and } \\
\text { exercise }\end{array}$ & 14 & 7 & 6 & 10 & 0 & 0 & 0 & 0 \\
\hline
\end{tabular}

${ }^{*} P<0.05 \quad-=$ Not Applicable

\subsubsection{Detection of existing diseases}

Of all first visit clients observed in the intervention and comparison clinics, no client received all the requisite observations, physical examinations and referrals (Table 13). Significantly more clients in the intervention clinics had their general appearance observed, had their blood pressure and respiratory rate taken, received a breast examination, and were referred for urine, syphilis and anaemia tests. However, there were fewer referrals for HIV tests in the intervention clinics than the comparison clinics during the four visits, an observation that was confirmed by exit interviews, which found that a larger proportion of clients ( $>70$ percent) in the comparison clinics than in the intervention clinics ( $<70$ percent) reported having discussed PMTCT and counselling and testing for HIV with providers over the course of four visits.

\begin{tabular}{|c|c|c|c|c|c|c|c|c|}
\hline \multirow[b]{2}{*}{ Procedures } & \multicolumn{4}{|c|}{$\begin{array}{c}\text { Intervention clinics (\%) } \\
(\mathrm{N}=12)\end{array}$} & \multicolumn{4}{|c|}{$\begin{array}{l}\text { Comparison clinics }(\%) \\
(\mathrm{N}=6)\end{array}$} \\
\hline & $\begin{array}{c}\mathrm{V}_{1} \\
\mathrm{~N}=72\end{array}$ & $\begin{array}{c}\mathrm{V}_{2} \\
\mathrm{~N}=72\end{array}$ & $\begin{array}{c}\mathrm{V}_{3} \\
\mathrm{~N}=72\end{array}$ & $\begin{array}{c}\mathrm{V}_{4} \\
\mathrm{~N}=60\end{array}$ & $\begin{array}{c}V_{1} \\
N=36\end{array}$ & $\begin{array}{c}\mathrm{V}_{2} \\
\mathrm{~N}=36\end{array}$ & $\begin{array}{c}V_{3} \\
N=36\end{array}$ & $\begin{array}{c}\mathrm{V}_{4} \\
\mathrm{~N}=35\end{array}$ \\
\hline Observe general appearance & 92 & $96^{* *}$ & 93 ** & $98^{*}$ & 77 & $69 * *$ & $64^{* *}$ & $85^{*}$ \\
\hline Take client's weight & 99 & 99 & 100 & 96 & 100 & 100 & 97 & 97 \\
\hline Take client's height & 4 & - & - & - & 0 & - & - & - \\
\hline
\end{tabular}




\begin{tabular}{|c|c|c|c|c|c|c|c|c|}
\hline Take clients' temperature & 0 & - & - & - & 0 & - & - & - \\
\hline Take client's pulse & 0 & - & - & - & 3 & - & - & - \\
\hline $\begin{array}{l}\text { Take blood pressure \& respiratory } \\
\text { rate }\end{array}$ & $97^{* *}$ & $93^{* *}$ & $94^{* *}$ & $80^{* *}$ & $56^{* *}$ & $50^{* *}$ & 50 ** & $49^{* *}$ \\
\hline $\begin{array}{l}\text { Check conjunctiva \& palms for } \\
\text { anaemia }\end{array}$ & 81 & 82 & 83 & 80 & 69 & 69 & 72 & 83 \\
\hline Examine breasts & 44 & $36^{*}$ & $36^{* *}$ & 33 & 34 & $14^{*}$ & $11^{\text {** }}$ & 14 \\
\hline Palpate for fundal height & 100 & 99 & 100 & 100 & 97 & 100 & 100 & 100 \\
\hline $\begin{array}{l}\text { Palpate abdomen for foetal } \\
\text { presentation }\end{array}$ & - & - & 100 & 100 & - & - & 94 & 100 \\
\hline Palpate abdomen for foetal lie & - & - & 85 & 88 & - & - & 100 & 91 \\
\hline $\begin{array}{l}\text { Palpate abdomen for engagement } \\
\text { of presenting part }\end{array}$ & - & - & - & 92 & - & - & - & 92 \\
\hline Listen to abdomen for foetal sounds & - & 90 & 97 & 100 & - & 100 & 100 & 100 \\
\hline $\begin{array}{l}\text { Refer client for urine test (protein, } \\
\text { sugar, acetone) }\end{array}$ & $81^{* *}$ & 29 & 7 & 3 & $19^{* *}$ & 16 & 0 & 0 \\
\hline Refer for a syphilis test & $90^{\star *}$ & - & - & - & $22^{* *}$ & - & - & - \\
\hline Refer for anaemia test & $93^{* *}$ & - & - & 7 & $28^{* *}$ & - & - & 0 \\
\hline Refer for HIV test & $29 * *$ & $19^{*}$ & $3^{*}$ & 7 & $58^{* *}$ & $42^{*}$ & $17^{*}$ & 31 \\
\hline \multicolumn{9}{|c|}{ Proportion of clients who received specific laboratory Investigations } \\
\hline Urine tests & $40^{* *}$ & 14 & 7 & 2 & $0^{* *}$ & 3 & 0 & 0 \\
\hline HIV tests (earliest opportunity) & 28 & 11 & $1^{* *}$ & 7 & 43 & 25 & $17^{* *}$ & 23 \\
\hline Blood test for HB (Anaemia test) & $64^{* *}$ & - & - & $8^{\star *}$ & $9^{* *}$ & - & - & $0 * *$ \\
\hline Syphilis test (visit 1 only) & $39^{* *}$ & - & - & - & $9^{* *}$ & - & - & - \\
\hline
\end{tabular}

Hardly any clients in the intervention or comparison clinics had their height, temperature and pulse taken during the first visit as required. Clients are expected to undergo a number of laboratory investigations, including urine test (for protein, sugar and acetone), HIV test, anaemia test (first visit only), syphilis test (first visit only) and blood test for haemoglobin (fourth visit only) to detect existing diseases. Even though the proportion of clients referred for laboratory investigations in the intervention clinics was significantly higher, fewer clients actually received the tests. Significantly more clients in the intervention clinics received a urine test, haemoglobin test and syphilis test than in the comparison clinics, where HIV testing was the main investigation done.

\subsubsection{Prevention of diseases and promotion of health}

During the first and fourth visits providers are expected to prescribe iron tablets, explain their purpose and explain the use of insecticide-treated bed nets to clients, and counsel clients on STI/HIV specific issues, danger signs in pregnancy and advice on self care. On the second and third visits, clients are expected to receive, in addition to these, a TT injection, an explanation of the purpose of TT, be asked if they are allergic to SP, given anti-malarial prophylaxis (first dose during second visit and second dose during third visit), an explanation on how to take SP and the purpose of preventive treatment with SP, an explanation of the importance of coming back for the second dose (second visit only), and asked about side effects from first dose of SP before being given the second dose (third visit only). 
Prevention of anaemia, tetanus and malaria in pregnancy: Over half the clients in the intervention and comparison clinics were given iron/folic acid during all visits, and providers in intervention clinics were more likely to explain the purpose of iron/folic acid during the third and fourth visits (Table 14). No variations were observed between the two groups on other aspects of managing anaemia in pregnancy.

\begin{tabular}{|c|c|c|c|c|c|c|c|c|}
\hline \multirow[b]{2}{*}{ Service components } & \multicolumn{4}{|c|}{ Intervention Clinics (\%) (N=12) } & \multicolumn{4}{|c|}{ Comparison Clinics (\%) $(\mathrm{N}=6)$} \\
\hline & $\begin{array}{c}\mathrm{V}_{1} \\
(\mathrm{~N}=72)\end{array}$ & $\begin{array}{c}\mathrm{V}_{2} \\
(\mathrm{~N}=72)\end{array}$ & $\begin{array}{c}\mathrm{V}_{3} \\
(\mathrm{~N}=72)\end{array}$ & $\begin{array}{c}\mathrm{V}_{4} \\
(\mathrm{~N}=60)\end{array}$ & $\begin{array}{c}\mathrm{V}_{1} \\
(\mathrm{~N}=36)\end{array}$ & $\begin{array}{c}\mathrm{V}_{2} \\
(\mathrm{~N}=36)\end{array}$ & $\begin{array}{c}\mathrm{V}_{3} \\
(\mathrm{~N}=36)\end{array}$ & $\begin{array}{c}\mathrm{V}_{4} \\
(\mathrm{~N}=35)\end{array}$ \\
\hline $\begin{array}{l}\text { Prescribe or give client } \\
\text { iron/folic acid }\end{array}$ & 64 & 50 & 58 & 47 & 51 & 58 & 53 & 54 \\
\hline $\begin{array}{l}\text { Explain purpose of } \\
\text { iron/folic acid }\end{array}$ & 43 & 38 & $46^{*}$ & $32^{*}$ & 34 & 34 & $22^{*}$ & $11^{*}$ \\
\hline $\begin{array}{l}\text { Explain how to take } \\
\text { iron/folic acid }\end{array}$ & 57 & 44 & 50 & 43 & 51 & 51 & 50 & 45 \\
\hline $\begin{array}{l}\text { Provide counselling on } \\
\text { using ITN }\end{array}$ & $39 * *$ & $45^{* *}$ & $36^{* *}$ & $32^{* *}$ & $3^{* *}$ & $3^{* *}$ & $0 * *$ & $0 * *$ \\
\hline $\begin{array}{l}\text { Ask client if allergic to SP } \\
\text { before prescribing }\end{array}$ & - & 1 & 0 & - & - & 0 & 0 & - \\
\hline $\begin{array}{l}\text { Explain prevention with } \\
\text { antimalarial medication }\end{array}$ & - & 32 & 10 & - & - & 19 & 8 & - \\
\hline $\begin{array}{l}\text { Prescribe or give anti } \\
\text { malarial prophylaxis }\end{array}$ & - & 63 & $18^{*}$ & - & - & 47 & $39 *$ & - \\
\hline $\begin{array}{l}\text { Explain how to take anti } \\
\text { malarial medication }\end{array}$ & - & 61 & $14^{*}$ & - & - & 47 & $39 *$ & - \\
\hline $\begin{array}{l}\text { Explain importance of } \\
\text { return for } 2^{\text {nd }} \text { dose of SP }\end{array}$ & - & 0 & - & - & - & 0 & - & - \\
\hline $\begin{array}{l}\text { Ask client about side } \\
\text { effects from } 1^{\text {st }} \text { dose of SP }\end{array}$ & - & - & 0 & - & - & - & 0 & - \\
\hline Give TT injection & - & 53 & 34 & - & - & 61 & 17 & - \\
\hline $\begin{array}{l}\text { Explain purpose of TT } \\
\text { injection }\end{array}$ & - & $24^{* *}$ & $18^{*}$ & - & - & $0 * *$ & $3^{*}$ & - \\
\hline
\end{tabular}

Significantly more clients in the intervention clinics received counselling on use of ITN, and providers at intervention clinics were more likely to prescribe the first dose of SP than the second dose, which was prescribed more frequently in the comparison clinics. Very few clients in all clinics were asked whether they were allergic to SP before prescribing, and none were given an explanation on the importance of returning for the second dose of SP or about the possible side effects from the first dose. Over half the clients received a TT injection during the second visit, with no differences between clinics. However, significantly more clients in the intervention clinics received an explanation on the purpose of the TT injection.

Counselling on STI/HIV/AIDS: Table 15 shows that, overall, a very small proportion of clients received counselling on STI/HIV issues in the intervention clinics during the four visits, and that significantly more clients in the comparison clinics received counselling on STI/HIV, PMTCT, and VCT. This reflects the fact that PMTCT had only just started to be introduced in the intervention clinics. 


\begin{tabular}{|l|c|c|c|c|c|c|c|c|}
\hline \multicolumn{7}{|c|}{ Table 15: Proportion of clients who received STI/HIV counselling during ANC visits, by visit and site } \\
\hline & \multicolumn{3}{|c|}{$\begin{array}{c}\text { Intervention clinics (\%) } \\
\text { (N=12) }\end{array}$} & \multicolumn{3}{c|}{ Comparison clinics (\%) } \\
(N=6)
\end{tabular}

\subsubsection{Preparation for birth and potential complications}

Birth planning is an important component of focused ANC and providers are expected to discuss it with clients during the first ANC visit and continue in the subsequent visits so that clients can plan appropriately for potential complications and delivery. As Table 16 shows, the intervention clinics performed significantly better than the comparison clinics. However, no clients received all the required information or were asked all the questions expected about birth planning - over 75 percent of clients received partial information only. Providers consistently provided selective information, thus undermining the comprehensiveness of focused ANC.

\begin{tabular}{|l|c|c|c|c|c|c|c|c|}
\hline \multicolumn{1}{|c|}{ Table 16: Proportion of clients who were counselled on birth planning and complication preparedness, } \\
by visit and site \\
\hline
\end{tabular}




\begin{tabular}{|l|c|c|c|c|c|c|c|c|}
\hline $\begin{array}{l}\text { Ask client where she plans } \\
\text { to deliver }\end{array}$ & $35^{* *}$ & $39^{* *}$ & $46^{* *}$ & $60^{* *}$ & $3^{* *}$ & $0^{* *}$ & $3^{* *}$ & $3^{* *}$ \\
\hline $\begin{array}{l}\text { Advise the client to use a } \\
\text { skilled health worker } \\
\text { during delivery }\end{array}$ & $53^{* *}$ & $46^{* *}$ & $53^{* *}$ & $75^{* *}$ & $3^{* *}$ & $6^{* *}$ & $14^{* *}$ & $6^{* *}$ \\
\hline $\begin{array}{l}\text { Ask the client about who } \\
\text { else will provide support }\end{array}$ & 8 & 10 & 7 & $23^{*}$ & 0 & 0 & 0 & $0^{*}$ \\
\hline Discuss birth partners & $11^{*}$ & $15^{*}$ & $11^{*}$ & $8^{*}$ & $0^{*}$ & $0^{*}$ & $0^{*}$ & $0^{*}$ \\
\hline $\begin{array}{l}\text { Advise client to involve } \\
\text { the birth partner in } \\
\text { making the IBP }\end{array}$ & 4 & 4 & 3 & 5 & 0 & 0 & 0 & 0 \\
\hline $\begin{array}{l}\text { Discuss the role to be } \\
\text { played by a birth partner }\end{array}$ & 4 & 4 & 3 & 5 & 3 & 0 & 0 & 0 \\
\hline $\begin{array}{l}\text { Advise client about } \\
\text { supplies to have on hand } \\
\text { at home }\end{array}$ & $17^{*}$ & $26^{* *}$ & $28^{* *}$ & $50^{* *}$ & $0^{* *}$ & $0^{* *}$ & $0^{* *}$ & $0^{*}$ \\
\hline $\begin{array}{l}\text { Ask about who will care } \\
\text { for the family during } \\
\text { delivery }\end{array}$ & 0 & 0 & 0 & 0 & 0 & 0 & 0 & 0 \\
\hline $\begin{array}{l}\text { Ask client about which } \\
\text { health care facility to go to } \\
\text { in case of complication }\end{array}$ & $21^{*}$ & $19^{*}$ & $26^{* *}$ & $28^{*}$ & $0^{*}$ & $3^{*}$ & $0^{* *}$ & $0^{*}$ \\
\hline $\begin{array}{l}\text { Asked client about } \\
\text { financial arrangements }\end{array}$ & $25^{*}$ & $32^{* *}$ & $36^{* *}$ & $53^{* *}$ & $0^{*}$ & $0^{* *}$ & $0^{* *}$ & $0^{* *}$ \\
\hline Advice on signs of labour & - & - & $31^{* *}$ & $40^{* *}$ & - & - & $3^{* *}$ & $9^{* *}$ \\
\hline
\end{tabular}

The frequency with which clients received information on birth planning on subsequent ANC visits was not high ( $>50$ percent). The only exceptions were asking clients about progress of the pregnancy ( $>60$ percent) and advising them to use a skilled health worker during delivery ( $>50$ percent). More than half of the fourth visit clients (53 percent) were also asked about their financial arrangements regarding basic expenses and additional funds if need be.

Who will care for the family during delivery was not asked at all in the intervention or comparison clinics. Exit interviews confirmed that that 48 percent of clients reported receiving information on birth planning during their first ANC visit, 47 percent in the second visit and 47 percent during the third visit. The proportion during the fourth visit was much higher (60 percent), as it appears that providers put more emphasis on IBP in the last trimester. One quarter of fourth visit clients reported in exit interviews that they had not heard about birth plans previously, further confirming this assertion.

An outstanding difference between the intervention and comparison clinics was the proportion of clients with whom symptoms/signs of labour were discussed during the third and fourth visits. Although a large of proportion of clients ( $>50$ percent) in the intervention clinics did not get this advice, the proportions were considerably higher than those recorded in the comparison clinics. 


\subsubsection{Counselling on plans for postpartum care}

As a comprehensive package, focused ANC encourages providers to counsel clients on postpartum care during the third and fourth visits. Clients should be advised on family planning after delivery, to attend a postpartum clinic at least twice, take their child for immunizations, care for their breasts, and exclusively breastfeed for up to 6 months. Table 17 shows that the proportion of clients who received counselling on postpartum family planning and were referred to a family planning clinic was significantly higher in the intervention clinics during the first visit than in the comparison clinics, where no-one was counselled on this at all. Counselling on other aspects of planning for postpartum care was also negligible.

\begin{tabular}{|l|c|c|c|c|}
\hline \multicolumn{6}{|l|}{ Table 17: Proportion of clients who received counselling on plans for postpartum care, by visit and site } \\
\hline Elements & $\begin{array}{c}\text { Intervention Clinics (\%) } \\
(\mathbf{N = 1 2})\end{array}$ & $\begin{array}{c}\text { Comparison Clinics (\%) } \\
(\mathbf{N}=\mathbf{6})\end{array}$ \\
\hline Aspects of counselling & $\begin{array}{c}\mathrm{V}_{3} \\
(\mathrm{~N}=72)\end{array}$ & $\begin{array}{c}\mathrm{V}_{4} \\
(\mathrm{~N}=60)\end{array}$ & $\begin{array}{c}\mathrm{V}_{3} \\
(\mathrm{~N}=36)\end{array}$ & $\begin{array}{c}\mathrm{V}_{4} \\
(\mathrm{~N}=35)\end{array}$ \\
\hline $\begin{array}{l}\text { Advise client to use birth control or family } \\
\text { planning after delivery }\end{array}$ & $18^{*}$ & 8 & $0^{*}$ & 0 \\
\hline Refer client to family planning clinic & $19^{*}$ & 8 & $0^{*}$ & 0 \\
\hline $\begin{array}{l}\text { Advise client to come to postpartum clinic at } \\
\text { least twice (at 6 days and at 6 weeks) after } \\
\text { delivery }\end{array}$ & 3 & 0 & 0 & 0 \\
\hline $\begin{array}{l}\text { Advise client to visit well baby clinic for } \\
\text { immunizations }\end{array}$ & 4 & 5 & 0 & 0 \\
\hline Advise on care of breasts and breastfeeding & - & 5 & - & 0 \\
\hline
\end{tabular}

$$
{ }^{*} \mathrm{P}<0.05 \quad-=\text { Not Applicable }
$$

\subsubsection{Encouraging continuity and follow-up}

Table 18 shows that one-third of the consultations in intervention and comparison clinics ensured privacy and confidentiality and informed clients on what was to be done and the due date. A larger proportion of clients ( $>50$ percent) in the intervention clinics were encouraged to ask questions than in the comparison clinics ( $<35$ percent). The date for return was given to more than 80 percent of clients in both intervention and comparison clinics. Providers in the comparison clinics always looked at and wrote on all client cards during the four visits, while some providers in the intervention clinics ignored this important practice.

Table 18: Proportion of client-provider interactions where continuity of care was ensured, by visit and 


\begin{tabular}{|l|c|c|c|c|c|c|c|c|}
\hline \multirow{2}{*}{ Elements } & \multicolumn{4}{|c|}{$\begin{array}{c}\text { Intervention clinics (\%) } \\
\text { (N = 12) }\end{array}$} & \multicolumn{4}{c|}{$\begin{array}{c}\text { Comparison clinics (\%) } \\
\text { (N =6) }\end{array}$} \\
\cline { 2 - 9 } & $\begin{array}{c}\mathrm{V}_{1} \\
(\mathrm{~N}=72)\end{array}$ & $\begin{array}{c}\mathrm{V}_{2} \\
(\mathrm{~N}=72)\end{array}$ & $\begin{array}{c}\mathrm{V}_{3} \\
(\mathrm{~N}=72)\end{array}$ & $\begin{array}{c}\mathrm{V}_{4} \\
(\mathrm{~N}=60)\end{array}$ & $\begin{array}{c}\mathrm{V}_{1} \\
(\mathrm{~N}=36)\end{array}$ & $\begin{array}{c}\mathrm{V}_{2} \\
(\mathrm{~N}=36)\end{array}$ & $\begin{array}{c}\mathrm{V}_{3} \\
(\mathrm{~N}=36)\end{array}$ & $\begin{array}{c}\mathrm{V}_{4} \\
(\mathrm{~N}=35)\end{array}$ \\
\hline $\begin{array}{l}\text { Ensured privacy, } \\
\text { confidentiality }\end{array}$ & 24 & 31 & 29 & 27 & 22 & 22 & 17 & 14 \\
\hline $\begin{array}{l}\text { Told client what was } \\
\text { to be done }\end{array}$ & 29 & 39 & 29 & 33 & 17 & 25 & 19 & 14 \\
\hline $\begin{array}{l}\text { Looked at clients } \\
\text { health card before } \\
\text { consultation }\end{array}$ & 100 & 100 & 99 & 98 & 100 & 100 & 100 & 100 \\
\hline $\begin{array}{l}\text { Asked client for any } \\
\text { concerns and } \\
\text { encourage questions }\end{array}$ & 53 & 57 & 54 & 51 & 33 & 25 & 25 & 23 \\
\hline Wrote on clients card & 100 & 61 & 68 & 68 & 100 & 100 & 100 & 100 \\
\hline $\begin{array}{l}\text { Informed clients } \\
\text { about due date }\end{array}$ & 21 & 19 & 35 & 44 & 25 & 0 & 6 & 20 \\
\hline $\begin{array}{l}\text { Gave client the return } \\
\text { date }\end{array}$ & 97 & 93 & 90 & 81 & 97 & 100 & 100 & 91 \\
\hline
\end{tabular}

\subsubsection{Provider and client satisfaction with focused ANC}

Providers expressed their willingness to provide focused ANC services as well as satisfaction with the approach. Client flow in the 12 intervention clinics was described as easy and smooth in most cases, with only three clinics reporting difficulties. All providers recommended focused ANC as the best approach to ANC. Providers who had worked with the traditional approach reported that they would opt for the comprehensive focused approach to ANC given a choice. Provider satisfaction was explained as follows:

"....The quality of service has improved tremendously. Initially, we conducted our services like 'a clearing house' with very little attention to visiting pregnant mothers. But since we now do individualized service the quality has improved (1 1 st Participant). The clients now know that our concern is not just the abdomen; we do more than that ( $2^{\text {nd }}$ participant). These days there are reduced cases of malaria in pregnancy in our clinics and the children born are of normal weight ( $3^{\text {rd }}$ participant)." (Provider FGD, Busia)

Providers commended the new approach of offering individualized ANC services by skilled personnel, which they said had ensured that pregnant women's specific health care needs were taken into consideration. The improvement in quality of care was attributed to the comprehensive nature of the focused ANC package and the fact that it had incorporated new services like IBP, PMTCT and IPT for malaria. Table 19 describes those aspects that providers found satisfactory and unsatisfactory about focused ANC.

Table 19: Provider satisfaction and concerns about focused ANC

\begin{tabular}{|c|c|}
\hline Aspects liked about focused ANC & Aspects not liked about focused ANC \\
\hline - $\quad$ Early detection of problems & - Time consuming e.g., too much client \\
\hline
\end{tabular}


- Birth planning

- Direct observed treatment short course (DOTS)

- Preventive services e.g., PMTCT, IPT

- Reduced number of visits

- It is user friendly

- Offers opportunity for increased institutional deliveries counselling

- Intensive workload

- Inability to do laboratory investigations on site and in time

- Inadequate training on some components of focused ANC

- Inadequate supplies - SP, reagents, iron supplements

Providers found specific elements of focused ANC satisfactory and beneficial to both providers and clients. For example, DOTS encouraged client compliance that is very essential in the control of diseases such as malaria. The reduced number of visits was understood to reduce provider workload overall, although they still complained of intensive workload.

Table 20 describes clients' satisfaction with various aspects of ANC. Clients in the intervention clinics were more dissatisfied with the waiting time than any other aspect of focused ANC, and consistently across all four visits with more than 50 percent of clients indicating their dissatisfaction during each visit. Satisfaction ratings were high (>70 percent) for all other aspects of ANC in the intervention and comparison clinics.

\begin{tabular}{|l|c|c|c|c|c|c|c|c|}
\hline \multicolumn{8}{|c|}{ Table 20: Proportion of clients satisfied with various aspects of focused ANC services } \\
\hline \multirow{2}{*}{ Services } & \multicolumn{3}{|c|}{ Intervention clinics (\%) } & \multicolumn{4}{c|}{ Comparison clinics (\%) } \\
\cline { 2 - 9 } & $\begin{array}{c}\mathrm{V}_{1} \\
(\mathrm{~N}=72)\end{array}$ & $\begin{array}{c}\mathrm{V}_{2} \\
(\mathrm{~N}=72)\end{array}$ & $\begin{array}{c}\mathrm{V}_{3} \\
(\mathrm{~N}=72)\end{array}$ & $\begin{array}{c}\mathrm{V}_{4} \\
(\mathrm{~N}=60)\end{array}$ & $\begin{array}{c}\mathrm{V}_{1} \\
(\mathrm{~N}=36)\end{array}$ & $\begin{array}{c}\mathrm{V}_{2} \\
(\mathrm{~N}=36)\end{array}$ & $\begin{array}{c}\mathrm{V}_{3} \\
(\mathrm{~N}=36)\end{array}$ & $\begin{array}{c}\mathrm{V}_{4} \\
(\mathrm{~N}=35)\end{array}$ \\
\hline Waiting time & 39 & 49 & 40 & 37 & 67 & 72 & 72 & 69 \\
\hline $\begin{array}{l}\text { Discuss } \\
\text { problems/concerns }\end{array}$ & 86 & 82 & 90 & 90 & 84 & 83 & 86 & 80 \\
\hline $\begin{array}{l}\text { Explanations by } \\
\text { providers }\end{array}$ & 75 & 81 & 89 & 92 & 78 & 83 & 83 & 80 \\
\hline $\begin{array}{l}\text { Quality of examination } \\
\text { and treatment provided }\end{array}$ & 86 & 85 & 94 & 92 & 89 & 92 & 89 & 80 \\
\hline Facility cleanliness & 86 & 83 & 86 & 90 & 81 & 89 & 89 & 83 \\
\hline Treatment by clinic staff & 72 & 68 & 75 & 72 & 94 & 81 & 81 & 89 \\
\hline
\end{tabular}

Table 21 shows the duration clients spent waiting for ANC services. Most clients spent between 1-2 hours waiting for ANC services in intervention clinics, while in the comparison clinics most clients spent between $30-45$ minutes.

Table 21: Waiting time for ANC services, by visit and site

\begin{tabular}{|l|c|c|c|c|c|c|c|c|}
\hline & \multicolumn{3}{|c|}{ Intervention clinics (\%) } & \multicolumn{4}{c|}{ Comparison clinics (\%) } \\
\hline Waiting time before services & $\begin{array}{c}\mathrm{V}_{1} \\
(\mathrm{~N}=72)\end{array}$ & $\begin{array}{c}\mathrm{V}_{2} \\
(\mathrm{~N}=72)\end{array}$ & $\begin{array}{c}\mathrm{V}_{3} \\
(\mathrm{~N}=72)\end{array}$ & $\begin{array}{c}\mathrm{V}_{4} \\
(\mathrm{~N}=60)\end{array}$ & $\begin{array}{c}\mathrm{V}_{1} \\
(\mathrm{~N}=36)\end{array}$ & $\begin{array}{c}\mathrm{V}_{2} \\
(\mathrm{~N}=36)\end{array}$ & $\begin{array}{c}\mathrm{V}_{3} \\
(\mathrm{~N}=36)\end{array}$ & $\begin{array}{c}\mathrm{V}_{4} \\
(\mathrm{~N}=35)\end{array}$ \\
\hline Saw provider immediately & 7 & 11 & 7 & 8 & 19 & 25 & 14 & 24 \\
\hline$<30$ minutes & 8 & 15 & 19 & 17 & 31 & 36 & 47 & 44 \\
\hline $30-45$ minutes & 22 & 17 & 14 & 10 & 19 & 17 & 33 & 18 \\
\hline
\end{tabular}




\begin{tabular}{|l|c|c|c|c|c|c|c|c|}
\hline 1 hour & 13 & 13 & 17 & 27 & 8 & 17 & 8 & 12 \\
\hline 2 hours & 19 & 25 & 17 & 17 & 17 & 6 & 6 & 3 \\
\hline 3 hours & 10 & 7 & 10 & 13 & 6 & 0 & 0 & 0 \\
\hline 4 hours \& above & 21 & 13 & 16 & 8 & 0 & 0 & 3 & 0 \\
\hline
\end{tabular}

Satisfaction ratings were consistently high in intervention and comparison clinics for discussion of problems/concerns, explanations given by providers, quality of examination, facility cleanliness, and treatment by clinic staff. When asked whether they would recommend a friend or relative to use the facility, over 85 percent of clients for all visits in intervention and comparison clinics answered in the affirmative.

While focused ANC is generally acceptable to clients, the findings indicate that they had a number of concerns. Clients cited the poor infrastructure and physical condition of clinics as one of the biggest impediments toward effective and sustainable implementation of focused ANC. Due to limited space, some crucial components of focused ANC, such as individualized counselling and laboratory tests, were not offered in some clinics.

Despite the government policy that ANC services are free and pregnant mothers should receive them at no cost, clients complained of being charged fees. Exit interviews showed that 65 percent of first, 52 percent of second, 49 percent of third and 53 percent of fourth visit clients had paid fees for various ANC services. The charges ranged from Kshs 10-120 (\$0.10 - 1.60) with the average being Kshs 20 (\$0.30). Clients who did not pay were reportedly exempted for one reason or another. While laboratory charges attracted the highest fee (Kshs 100.00, \$1.30), other fees were charged for a rubber stamp, registration cards, a "development fund," and medicines.

\subsection{Discussion}

The focused ANC package has expanded the content of ANC to include additional components such as selective history taking according to visit, IBP, IPT, PMTCT and counselling on plans for postpartum care including family planning. Some of these new components have been integrated, to a certain extent, into the package that women receive when they visit those clinics that had been part of the focused ANC program. At the time of the study, however, postpartum family planning and PMTCT were limited, and screening for TB was still offered as a specialized stand-alone service without any link to focused ANC. Some services (e.g. PMTCT) are offered on specific days, limiting the degree of comprehensiveness possible, as well as discouraging utilization of these services. Limited availability of essential drugs and laboratory supplies, although a concern for any ANC model, was also a problem for focused ANC services in the intervention clinics.

Focused ANC has been introduced in the absence of an explicit RH policy, and in a situation where separate service standards and guidelines are available for many component services (e.g. PMTCT, Malaria and TB). Donor emphasis on certain components and not all has further contributed to a lack of coherence in program 
introduction and implementation, which has further fragmented ANC service delivery.

Timing of ANC visits is largely unchanged. Focused ANC is a scheduled service, and when clients do not adhere to the recommended timing, the very purpose of the service is challenged. Much still needs to be done to make compliance with the timing of focused ANC visits more feasible, but it also clear that what triggers pregnant women to change their ANC service utilization may be more than just a reduction in the number of visits.

Provider capability to provide the range of services required for focused ANC remains weak in some aspects, and most providers had limited knowledge of which routine services are expected for focused ANC, including critical aspects like the timing of visits, PMTCT, and many aspects of education and counselling. Although most providers in the intervention clinics were knowledgeable in ways of controlling malaria in pregnancy, as this had received particular attention at the request of the donor and the $\mathrm{MOH}$, more resources will need to be directed towards training providers to fill the knowledge gap in many aspects of focused ANC.

Refocusing ANC was expected to result in significantly better quality of care. Introduction of focused ANC has had a positive effect on quality of care overall. In particular, preparation for birth and awareness of potential complications, detection of existing diseases and counselling on postpartum care were significantly improved. No improvement was noted, however, in the quality of history taking, prevention and promotion of health, and encouraging continuity. These aspects of focused ANC will need increased attention as the package is rolled-out across the country over the coming years.

Providers definitely prefer focused ANC because it has revolutionized the delivery of ANC services. The complaints recorded were mainly administrative and infrastructure-related, and not inherent to the approach itself. For instance, the intensive workload and inadequate training could be solved by deploying well trained staff while the shortage experienced in supplies cuts across all RH services.

While clients living in the catchment areas were mostly aware of focused ANC, their knowledge of its component services, especially PMTCT and IBP, was limited probably because these services had not been introduced within the overall package of services included in the pilot project and initial scale-up. Most clients still held the view that they were required to make monthly visits to ANC clinics, which could be due to the failure of providers to communicate this, or an indication that, despite their training in focused ANC, service providers still retain existing notions about the delivery of ANC. It is essential, however, that clients do have full knowledge of how ANC is now being offered, and the reasons why, suggesting that more attention needs to be given to community education when the new package is introduced into a district. 
Focused ANC was acceptable to clients, but the longer waiting time that it seems to have created will have to be addressed, as it is unacceptable to many clients. The longer waiting time could be due to poor organization of the new services and their configuration, which needs to be explicitly considered whenever it is introduced. Another source of concern for clients is the levying of fees on some ANC services, but again this occurs across existing and new configurations of ANC. It means, however, that every time a new service is introduced it may come with additional costs, formal or otherwise, for the clients, which could raise the overall cost of ANC to clients.

The biggest constraint to sustaining focused ANC is the adequacy of funding available at the district level for offering the increased range of services. In the absence of sufficient funding from the Government, introduction of focused ANC has largely depended on support from health development partners. This reliance on external funding subjects the rollout and routine implementation of focused ANC to shifting donor priorities, and services are likely to grind to a halt once donors complete their funding. It is hoped that creation of a reproductive health policy and increased attention to sector-wide funding will pave the way for the allocation of funds explicitly for focused ANC, given that it is a priority to the $\mathrm{MOH}$ because it is a critical means for achieving the MDGs. Whether development partners would agree to such a prioritization given their current focus on addressing HIV, remains to be seen.

Apart from financial constraints, the sustainability of focused ANC is also constrained by the lack of involvement of the pre-service training institutions and professional bodies in the initial design and planning for its introduction and implementation. To date, the training curricula for ANC in pre-service training institutions have remained unchanged. The non-involvement of the professional associations in the initial stages may partly explain the absence of articulated standards and full embracement of the concept, especially by supervisors.

\subsection{Conclusions and Recommendations}

Focused ANC is acceptable to both clients and providers. The approach has also received tremendous support from the government and health development partners. However, the sustainability of the focused ANC package is contingent upon:

- Continued availability of funding;

- Increased equipment and supplies needed to offer these services at clinics providing ANC;

- Training providers so that they are fully competent in all the component services, and able to offer them in an integrated fashion;

- Ensuring that supervisors are able to support and enable providers to deliver integrated, comprehensive ANC services;

- Communicating the new regimen of services and their timing to the general public so that ANC attendance is both earlier and according to the four-visit schedule. 
Sustainability of the focused ANC package will also require explicit policy direction and coordinated $\mathrm{RH}$ program implementation and support. The process of stimulating changes in ANC service delivery will require further consultation with and inclusion of key actors, notably the pre-service training institutions and professional bodies, to ensure institutionalization and standardization of focused ANC training and supervision. Related to this is the need to update the curricula and training materials to be able to present focused ANC as a comprehensive and integrated service, rather than an aggregation of services that a provider may or may not be able to offer.

Community mobilization when the new package is introduced is still required to create awareness about IBP, timing of ANC and the need to co-opt other critical actors, especially male partners, in preparation for birth and complications. A national educational campaign may help in this regard.

Waiting time and informal fees are an expressed concern for clients who have received focused ANC, and so there is an urgent need to consider reorganizing services and/or client flow to reduce client waiting time and to clarify the policy on user fees at service delivery level.

In summary, introduction of focused ANC in Kenya has successfully started and should be continued given its acceptability and effect on the quality of care received. This study provides many insights into ways in which expansion of this approach to ANC could be strengthened, both to further improve the quantity, quality and relevance of services received by pregnant women, and to enhance the likelihood that such a comprehensive and integrated service can be sustained as a routine best practice. 


\subsection{References}

Chege J, Askew I, Mosery N, Nxumalo MN, Kunene B, Beksinska M, Dalton J, Snyman E, Sturm W, Moodley P. 2005. Feasibility of introducing a comprehensive integrated package of antenatal care services in rural public clinics in South Africa, Frontiers in Reproductive Health Program, Population Council, Johannesburg, South Africa.

Central Bureau of Statistics (CBS)[Kenya], Ministry of Health (MOH) [Kenya], ORC Macro 2004 Kenya Demographic and Health Survey 2003. Calverton, Maryland: CBS, MOH and ORC Marco.

Ferguson A, Gachuhi M, Ndwiga C, Njoroge P, Sekento J, Lynam P, and C. Andere 2000 Malaria in Pregnancy: Report of Baseline Findings for Knowledge Attitudes and Practice for Intermittent Presumptive Treatment in Two MalariaEndemic District of Kenya, DFID Grant number AG031-555-037-BA-033, JHPIEGO, Nairobi, Kenya.

Division of Reproductive Health. 2004. Business Plan 2004/2005, Ministry of Health, Nairobi, Kenya.

Division of Reproductive Health. 2005. Business Plan 2005/2006, Ministry of Health, Nairobi, Kenya.

Ministry of Health. 1998. Implementation Plan for National Reproductive Health Strategy 1999-2003, Ministry of Health, Nairobi, Kenya.

Ministry of Health. 1997. National Guidelines for Diagnosis, Treatment and Prevention of Malaria for Health care Workers, Ministry of Health, Nairobi, Kenya.

Ministry of Health. 1998. Malaria: A Situational Analysis for Kenya, Ministry of Health, Nairobi, Kenya.

Ministry of Health [Kenya], National Council for Population and development [Kenya] and ORC Macro. 2000. Kenya Service Provision Assessment Survey 1999. Calverton, Maryland: Ministry of health, National Council for Population and Development, and ORC Macro.

MOH-DRH, DOMC and JHPIEGO. 2002 Focused Antenatal Care and Malaria in Pregnancy: Orientation package, Ministry of Health, Nairobi, Kenya. 
Ministry of Health, Division of Reproductive Health. 2002. National Guidelines for Quality Obstetrics and Perinatal Care, Ministry of Health, Nairobi, Kenya.

Ministry of Health. (undated) National Reproductive Health Strategy 1997-2010, Ministry of Health, Nairobi, Kenya.

Ministry of Health. 2002. National Guidelines for Prevention of Mother-to-Child HIV/AIDS Transmission (PMTCT). National AIDS and STD Control Programme (NASCOP), Ministry of Health, Nairobi, Kenya. Second Edition.

Ministry of Health. 2004. Busia District Health Services Work Plan 2004-2005, Ministry of Health, Nairobi, Kenya.

Ministry of Health. 2003. Lugari District Annual Health Report 2003, Ministry of Health, Nairobi, Kenya.

Ministry of Health. 2005 Kenya Health Sector HIV / AIDS Strategic Plan 2005 -2010, Ministry of Health, Nairobi, Kenya. Final Draft.

Ministry of Health. 2003. Focused Antenatal Care and Malaria in Pregnancy: followup survey of four malaria-endemic districts in Kenya, Division of Reproductive Health and Division of Malaria Control. DFID Grant No. AG031-555-037-CA-001.

National Council for Population and Development (NCPD), Central Bureau of Statistics (CBS) (office of the Vice President and Ministry of Planning and National Development) [Kenya], Marco International Inc. (MI). 1999. Kenya Demographic and Health Survey 1998. Calverton, Maryland: NDPD, CBS, and MI.

Nganda, B. 2003. The Safe Motherhood Programme in Kenya: A Unit Costing Study. Report submitted to Division of Reproductive Health, Ministry of Heath, Nairobi, Kenya.

Parise, ME., Lewis, LS., Ayisi JG., Nahlen BL., Slutsker, Muga R., Shalif SK., Hill J. \& RW. Steketee 1998. “Efficiency of Sulfadoxine-Pyrimethamine for Prevention of Placental Malaria in an area of Kenya with a high prevalence of Malaria and Human Immunodeficiency Virus Infection", American Journal of Tropical Medicine and Hygiene 59:813-822.

Solo, J. Maggwa, N. Wabaru, JK. Kariuki, BK. And G. Maitha. 1999. Improving the Management of STIs among MCH/FP Clients at the Nakuru Municipal 
Council Health Clinics, Africa Operations Research and Technical Assistance Project II, Population Council, Nairobi, Kenya.

Temmerman, M., Fonk, K., Bashir, F., et al. 1999. “Declining syphilis prevalence in pregnant women in Nairobi since 1995: Another success story in the STD field?", Int. J. STD and AIDS, 10: 405-408.

Villar J, Ba'aqeel H, Piaggio G, Lumbiganono P, Belizan JM, Farnot U, Al-Mazrou Y, Carroli G, Pino A, Donner A, Langer A, Nigenda G, Mugford M, Fox-Rushby J, Hutton G, Bergsjo P, Berebdes H. 2001. "WHO antenatal care randomized trial for the evaluation of a new model of routine antenatal care", The Lancet, 357: 1565-1570.

Valadez, JJ. Loolpapit, PM. Diki, F. Nyagao, A. 1999. “HIV and syphilis sero-status of antenatal in traditional Maasai pastoralist communities in Kajiado District Kenya: 1989-1992", Tropical Doctor, 29(2): 94-98.

Walt, G, Gilson, L. 1994. "Reforming the health sector in developing countries: The central role of policy analysis", Health Policy and Planning. 9: $353-370$. 


\section{Annex 1}

\begin{tabular}{|c|c|c|c|c|}
\hline \multicolumn{5}{|c|}{ Focused Antenatal Care Checklist } \\
\hline & \multicolumn{4}{|c|}{ Weeks of gestation } \\
\hline Parameters & $\begin{array}{l}1^{\text {st }} \text { Visit } \\
<16 \text { weeks }\end{array}$ & \begin{tabular}{|l|}
$20-24$ \\
Weeks
\end{tabular} & $\begin{array}{l}28-32 \\
\text { Weeks }\end{array}$ & $\begin{array}{l}36 \\
\text { Weeks }\end{array}$ \\
\hline \multicolumn{5}{|l|}{ Registration } \\
\hline \multicolumn{5}{|l|}{ Comprehensive history taking } \\
\hline Personal history & $\mathrm{X}$ & & & \\
\hline Family history & $\mathrm{X}$ & & & \\
\hline Social history & $\mathrm{X}$ & & & \\
\hline Past medical/surgical history & $\mathrm{X}$ & & & \\
\hline Past obstetric history & $X$ & & & \\
\hline History of current pregnancy & $X$ & & & \\
\hline History of complaints in current pregnancy & $X$ & $X$ & $X$ & $X$ \\
\hline \multicolumn{5}{|l|}{ Physical Examination } \\
\hline Head-to-toe (whole body) & $X$ & $X$ & $\mathrm{X}$ & $X$ \\
\hline Pallor & $X$ & $X$ & $\mathrm{X}$ & $\mathrm{X}$ \\
\hline Oedema & $\mathrm{X}$ & $\mathrm{X}$ & $\mathrm{X}$ & $\mathrm{X}$ \\
\hline Breast & $X$ & $X$ & $\mathrm{X}$ & $\mathrm{X}$ \\
\hline Lung and heart & $X$ & & & \\
\hline \multicolumn{5}{|l|}{ Observations and clinical investigations } \\
\hline Temperature & $\mathrm{X}$ & & & \\
\hline Pulse & $X$ & & & \\
\hline Blood pressure & $\mathrm{X}$ & $X$ & $\mathrm{X}$ & $X$ \\
\hline Weight & $X$ & $X$ & $\mathrm{X}$ & $\mathrm{X}$ \\
\hline Height & $\mathrm{X}$ & & & \\
\hline Gait & $\mathrm{X}$ & & & \\
\hline \multicolumn{5}{|l|}{ Obstetric examination } \\
\hline Fundal height & $X$ & $\mathrm{X}$ & $\mathrm{X}$ & $\mathrm{X}$ \\
\hline Foetal poles/lie & & & $X$ & $X$ \\
\hline Foetal presentation & & & $\mathrm{X}$ & $\mathrm{X}$ \\
\hline Engagement of presenting part & & & & $X$ \\
\hline Foetal heart sounds & & $\mathrm{X}$ & $X$ & $X$ \\
\hline \multicolumn{5}{|l|}{ Pelvic (vaginal) examination } \\
\hline $\begin{array}{l}\text { Soft tissue assessment (genital ulcers, vaginal } \\
\text { discharge, cervix, uterine enlargement position, } \\
\text { adnexal masses) }\end{array}$ & $X$ & & & $X$ \\
\hline Bony pelvis assessment (cephalopelvic relationship) & & & & $X$ \\
\hline \multicolumn{5}{|l|}{ Laboratory investigations } \\
\hline \multicolumn{5}{|l|}{ Blood } \\
\hline Haemoglobin & $\mathrm{X}$ & & & $X$ \\
\hline Grouping and rhesus factor & $\mathrm{X}$ & & & \\
\hline VDRL for syphilis testing & $\mathrm{X}$ & & & \\
\hline HIV testing (earliest opportunity) & $\mathrm{X}$ & & & \\
\hline \multicolumn{5}{|l|}{ Urine } \\
\hline Protein & $\mathrm{X}$ & $X$ & $\mathrm{X}$ & $X$ \\
\hline Sugar & $X$ & $X$ & $\mathrm{X}$ & $\mathrm{X}$ \\
\hline Acetone & $X$ & $X$ & $\mathrm{X}$ & $\mathrm{X}$ \\
\hline \multicolumn{5}{|l|}{ Drug Administration and immunization } \\
\hline Iron & $\mathrm{X}$ & $X$ & $X$ & $X$ \\
\hline Folic acid & $\mathrm{X}$ & $\bar{X}$ & $X$ & $X$ \\
\hline
\end{tabular}




\begin{tabular}{|c|c|c|c|c|}
\hline \multicolumn{5}{|c|}{ Focused Antenatal Care Checklist } \\
\hline Anti-malarials (Fansidar 3 tablets) & & & $\mathrm{X}$ & $\mathrm{X}$ \\
\hline Tetanus toxoid & & $\mathrm{X}$ & $\mathrm{X}$ & \\
\hline \multicolumn{5}{|l|}{ Client education \& counselling (for couple) } \\
\hline Process of pregnancy \& its complications & $\mathrm{X}$ & $\mathrm{X}$ & $\mathrm{X}$ & $\mathrm{X}$ \\
\hline Diet and nutrition & $\mathrm{X}$ & $\mathrm{X}$ & $\mathrm{X}$ & $\mathrm{X}$ \\
\hline Rest and exercise in pregnancy & $\mathrm{X}$ & $\mathrm{X}$ & $\mathrm{X}$ & $\mathrm{X}$ \\
\hline Personal hygiene & $\mathrm{X}$ & $\mathrm{X}$ & $\mathrm{X}$ & $\mathrm{X}$ \\
\hline Danger signs in pregnancy & $\mathrm{X}$ & $\mathrm{X}$ & $\mathrm{X}$ & $\mathrm{X}$ \\
\hline Use of drugs in pregnancy & $\mathrm{X}$ & $\mathrm{X}$ & $\mathrm{X}$ & $\mathrm{X}$ \\
\hline Effects of STI/HIV/AIDS & $\mathrm{X}$ & $\mathrm{X}$ & $\mathrm{X}$ & $\mathrm{X}$ \\
\hline Voluntary confidential counselling and testing for HIV & $\mathrm{X}$ & & & \\
\hline Care of breasts \& breast feeding & $\mathrm{X}$ & & & $\mathrm{X}$ \\
\hline Symptoms/signs of labour & & & $\mathrm{X}$ & $\mathrm{X}$ \\
\hline $\begin{array}{l}\text { Plans for delivery (emergency preparedness, place of } \\
\text { delivery, transport, financial arrangements) }\end{array}$ & $\mathrm{X}$ & $\mathrm{X}$ & $x$ & $\mathrm{x}$ \\
\hline Plans for postpartum care & & & $\mathrm{X}$ & \\
\hline Family planning & & & $\mathrm{X}$ & $\mathrm{X}$ \\
\hline Harmful habits (smoking, drug abuse, alcoholism) & $\mathrm{X}$ & $\mathrm{X}$ & $\mathrm{X}$ & $\mathrm{X}$ \\
\hline Schedule of return visits & $\mathrm{X}$ & $\mathrm{X}$ & $\mathrm{X}$ & $\mathrm{X}$ \\
\hline
\end{tabular}

Source: MOH-DRH/DOMC/JHPIEGO July 2002 Focused Antenatal Care and Malaria in pregnancy. Orientation package 